\title{
Networks for the commercialization of innovations: A review of how divergent network actors contribute
}

This is a self-archived version of a manuscript accepted for Industrial Marketing Management DOI: https://doi.org/10.1016/j.indmarman.2013.12.005

\author{
Authors: \\ Leena Aarikka-Stenroos (corresponding author) \\ Turku School of Economics, University of Turku \\ Department of Marketing and International Business \\ Address: Turku School of Economics, FI-20014 University of Turku, Finland \\ Tel. +35823339229 \\ Fax: +35823338900 \\ E-mail: leena.aarikka-stenroos@utu.fi
}

Birgitta Sandberg

Turku School of Economics, University of Turku

Department of Marketing and International Business

Address: Turku School of Economics, FI-20014 University of Turku, Finland E-mail: birgitta.sandberg@utu.fi

Tuula Lehtimäki

University of Oulu

Department of Marketing 
Address: P.O. Box 4600, FI-90014 University of Oulu, Finland.

E-mail: tuula.lehtimaki@oulu.fi

Biographies:

Dr. Leena Aarikka-Stenroos is a Senior Researcher at the Department of Marketing and International Business, Turku School of Economics, University of Turku. Her research focuses on business marketing, knowledge intensive services, the commercialization of innovations, and the role of networks in innovation and service businesses. Her articles have been published in e.g. Industrial Marketing Management, Journal of Business Research and international books.

Dr. Birgitta Sandberg is a Post-doctoral Researcher at the Department of Marketing and International Business, Turku School of Economics, University of Turku. Her main research interests include the development and marketing of radical innovations, entrepreneurial innovators, and the role of emotions in innovation processes. Her publications include a book entitled Managing and Marketing Radical Innovations; Marketing New Technology (Routledge, 2008), and articles in e.g. Journal of Business Research, Technovation, and European Journal of Innovation Management.

Tuula Lehtimäki is a doctoral candidate at Oulu Business School. Her main research interests include new product launch, commercialization, business models, and innovation management. She is published, for example, in Industrial Marketing Management and International Journal of Technology Marketing.

\section{Acknowledgements}

The authors gratefully acknowledge the contributions from the anonymous reviewers and the guest 
editors Professors Per Vagn Freytag and Louise Young whose constructive advices improved the article. Thanks also to all the commenters at the research workshop of University of Oulu for their inspiring comments on the early version of the article. The authors are also grateful to the Foundation for Economic Education for providing a grant for this research.

Research highlights:

- The extant research on networks facilitating commercialization is scattered across divergent disciplines.

- Through a metatheoretical literature review we integrate the knowledge on the network approach in commercialization.

- Divergent network approaches - such as strategic, industrial, and social networks - are linked to commercialization.

- Network actors as contributors can perform commercialization tasks, facilitate adoption/diffusion and create markets.

- This article generates an integrative framework on how contributors can facilitate the commercialization of innovations. 


\begin{abstract}
Successful commercialization is of great importance to innovative firms, and the recent literature has increasingly acknowledged that networks make a contribution not only to research and development but also to commercialization. A single company is rarely capable of generating successful diffusion in the commercialization of an innovation; success often requires cooperation between individual actors and organizations, and support from stakeholders. However, research on networks facilitating the commercialization of innovations is scattered across divergent disciplines. The aim of this study is thus, on the basis of an extensive, multidisciplinary, metatheoretical literature review, to integrate the extant knowledge on networks for commercialization and analyze how contributors external to the innovator firm can facilitate commercialization. The analysis identified divergent network approaches to commercialization, such as industrial networks, social networks, strategic networks, and entrepreneurship networks. According to the findings, customers and user communities, distributors, complementaries, suppliers, investors, associations, public organizations, and policy makers and regulators can perform diverse practical commercialization tasks, facilitate innovation adoption/diffusion and create markets. This article contributes by generating an integrative framework and a research agenda on networks for commercialization - a theme that is emergent, multifaceted, and crucial to innovative companies.
\end{abstract}

Keywords: commercialization, launch, innovation adoption, innovation diffusion, networks, relationships

Article classification: Literature review 


\section{INTRODUCTION}

Innovations are increasingly developed within networks and hence there is a great deal of research being conducted on how networks and collaboration contribute to innovation development. However, commercialization in particular is known to be a critical part of the innovation process and most innovations fail in that phase (Chiesa \& Frattini, 2011; Di Benedetto, 1999). Challenges in commercialization originate from the novelty of innovations which complicates the adoption of new solutions by raising adoption barriers, and leads customers and other actors in the business environment to resist new solutions (Chiesa \& Frattini, 2011; More, 1983). Few firms have the capability to develop and manage innovations internally; success often requires cooperation between individual actors and organizations (e.g., Story, Hart, \& O’Malley, 2009). And especially in commercialization, a new product or service requires acceptance and diffusion among networked market actors; it tends to fail if it does not attract support from stakeholders (Talke \& Hultink, 2010).

As a single company is rarely capable of generating successful diffusion in the commercialization of an innovation, the network aspect in commercialization is crucial. To have a product with supreme technical features alone is often not enough. Due to the interconnectedness of market actors and technologies, innovation adoption is impacted by many interrelated organizations and individuals who reciprocally influence each other's behavior, and who will not switch to a new product unless they are convinced that most of the other players will also switch - a situation that is highly typical to some industries, such as interconnected high-tech (see Chakravorti, 2004; Chiesa \& Frattini, 2011). In sum, network players' support is needed to promote an innovation in commercialization.

So the question is how network actors can support innovator firms in commercializing new products and services. Recent research has increasingly indicated that network actors can contribute not only to R\&D but also to divergent aspects of commercialization. In the field of innovation management, research has shown that small innovator firms can commercialize their innovations by 
combining resources in their networks to enter new foreign markets (Tolstoy \& Agndal, 2010), and that adoption networks that may facilitate innovation adoption determine how an innovation might succeed in markets (Chiesa \& Frattini, 2011). Investigations have shown that user networks can be activated to support product launch (Harrison \& Waluszewski, 2008), and peer networks create community pull effects (Hienert \& Lettl, 2011); thereby emphasizing the users' contribution to commercialization. According to recent entrepreneurship research, a portfolio of network relations with suppliers, distributors and customers helps small, new innovative firms acquire resources to commercialize incremental and radical innovations (Partanen, Chetty, \& Rajala, 2011). In the field of business and marketing, recent research emphasizing interorganizational networks (particularly the IMP school) has evidenced that an innovator firm can intentionally activate its divergent network relations to advance commercialization and innovation success as an element of the firm's commercialization competence (Aarikka-Stenroos \& Sandberg, 2012; Aarikka-Stenroos \& Lehtimäki, 2013). Relational competences of firms developing radical innovations can be deployed also for commercialization (Story et al., 2011). Research emphasizing innovation networks has noted that the shift of resources from in-house commercialization activities towards collaboration with distributors and other actors seems to enhance commercialization success (Perks \& Moxey, 2011). Furthermore, the literature emphasizing the strategic network approach suggests that innovative firms' networking creates new fields of business and markets for innovations (Möller \& Rajala, 2007; Möller \& Svahn, 2009). Our study thus assumes that diverse networks and relations can help overcome commercialization challenges, advancing commercialization by providing manifold complementary support and resources, and establishing a supportive context in which a new product might endure.

Even though findings by previous researchers indicate divergent network actors' crucial impact on commercialization and the relevance of the phenomenon, the extant literature does not provide systematic or integrative analysis of the divergent network actors contributing to the 
commercialization; consequently, we still lack knowledge on networks for commercialization. Given the centrality of commercialization to innovation success, it is vital that contemporary research generates a deeper understanding on the value of relationships, networks, and interactions to the commercialization of innovations. However, the pace and disconnect of rapidly expanding research also generates a situation in which the knowledge on networks for commercialization does not accumulate. Therefore, the aim of this study is to aggregate the current knowledge on how contemporary research and business have employed the network approach in commercialization, and construe how contributors external to the innovator firm can contribute to the commercialization of innovations. We favor the school of thought which states that the innovator firm can intentionally develop and orchestrate its network relations with divergent actors for commercialization; our assumption thus follows the basic notions of the strategic network approach (e.g., Gulati, 1998; Möller \& Rajala, 2007). We perceive that knowledge on how to employ networks for commercialization is becoming increasingly important for companies facing ever tighter financial conditions and growing competition, and for researchers who aim to advance understanding on the role of networks in the development and diffusion of innovations.

To integrate and structure the extant knowledge on networks for commercialization, this article conducts an extensive metatheoretical literature review (see Torraco, 2005). To map the multidisciplinary research area, we first answer the following research questions: 1) How are networks for commercialization discussed in the current research (i.e., the main approaches, the key concepts and terms related to networks for commercialization)? 2) What are the current research methods and which kinds of innovation and context are studied with regard to networks for commercialization? We will then be better positioned to answer our ultimate research question: 3 ) What kinds of network actor contribute to commercialization and how do they contribute? In order to answer these three questions we employed a multidisciplinary database, Ebsco Business Source, to identify articles linking networks to commercialization, and analyzed them through systematic 
content analysis.

This article makes a pivotal contribution inasmuch as it is the first to generate an integrative framework on networks for commercialization - a theme that is emergent, multifaceted, and crucial to innovative companies. The analysis also seeks to clarify the incoherent terminology that originates from the diversity of approaches to the phenomenon. Mapping this rapidly evolving research, which links networks and commercialization both in content and methods will enable researchers and managers to employ current knowledge in their research and businesses more effectively; for example, researchers could position their studies more appropriately and practitioners become aware of the full contribution potential of network actors in their innovation business. We will also generate an agenda for further research as an outcome of our analysis.

Our paper is structured as follows. First, we present a short theoretical review with definitions of relevant concepts, such as networks and commercialization. The next section explains the methodology associated with the collection of the research data, and the content analysis of the identified research articles. We then identify key findings regarding networks for commercialization, propose a synthesis of commercialization networks, key actors, contributions, and their applicability to diverse innovation contexts, and construct an integrative framework on networks for commercialization. Theoretical and managerial implications follow as the research results enable us to suggest directions for researchers to study commercialization and networks, and to develop terminology; and for managers to develop the application of divergent networks for commercialization within divergent innovation industries. Finally, we discuss the limitations of the paper.

\section{THEORETICAL FOCUS AND KEY CONCEPTS ON NETWORKS FOR COMMERCIALIZATION}

The term network for commercialization can be linked to divergent network approaches with 
different thematic emphases and background assumptions. Multiple established network approaches include for example strategic networks, industrial networks (IMP), social networks, innovation networks, network theory, and the economics of networks (see Table 1). The network approaches differ particularly in terms of the respective focal actors, what determines the network, and how the actors are managed (see e.g., Easton \& Araujo, 1996). The networks also have internal linkages and confrontations; for example, innovation networks tend to apply strategic network assumptions, and IMP network and strategic network approaches disagree on the aspect of network management. The current divergent network research in relation to commercialization has studied both organizations' strategic or operational collaboration for commercialization (e.g., Perks \& Moxey, 2011; Möller \& Rajala, 2007; Partanen et al., 2011) and individuals' impact on successful adoption improving commercialization (e.g. Hienert \& Lettl, 2011). In this study, network for commercialization refers to an extensive group of actors who contribute to the commercialization of an innovation.

\section{INSERT TABLE 1 HERE}

The innovation concept encompasses ideas of economic leadership and commercial success (Schumpeter, 1934); to become an innovation an invention has to be commercially successful, which presumes both a successful product or service launch and diffusion in the market. In the literature, the term "innovation" is employed to describe both radical, breakthrough novelties and incremental, modest novelties (Mohr, 2001; Garcia \& Calantone, 2002). As this article aims to capture the diversity of the literature, we employ the term innovation in its broader sense; for instance, encompassing both radical and incremental novelties. The latter are often termed new products or services.

There is variation also between the concepts of commercialization, launch, diffusion, and adoption which arises from their different perspectives. Commercialization and launch emphasize the 
innovator firm's perspective. Commercialization tends to refer to how an innovator firm can accrue income from its new product, service, concept, or technology; it includes divergent, strategic and tactical planning, and marketing activities concerning the product/concept, launch, and interactive activities with potential buyers and other relevant players (e.g., Jolly, 1997). The term launch refers to the specific introduction of the new product/concept to markets and its follow-up (Crawford \& Di Benedetto, 2008; Di Benedetto, 1999). In commercialization and launch, a firm needs to focus on tasks such as the creation of demand, acquisition of marketing resources, effective communication with end users to facilitate adoption, building national and international distribution channels, and accessing market and customer information (Di Benedetto, 1999; Easingwood, Moxey, \& Capleton, 2006). Noteworthy is that $R \& D$ and commercialization activities may overlap and interact during the innovation process (Aarikka-Stenroos \& Lehtimäki, 2013; Prebble, de Wall, \& de Groot, 2008; Prenkert, 2012).

The terms adoption and diffusion, on the other hand, emphasize the market's and market actors' perspectives: diffusion refers to how the innovation spreads and diffuses in markets, whereas adoption describes how the innovation is adopted and accepted for use (Rogers, 1983; Christensen, 1992). Adoption and diffusion thus determine the success of innovation, and are constitutive concepts in examining commercialization.

In sum, the key concept of this research is commercialization, as our focus is on the innovator firm's perspective. However, interrelationships between the above mean that these other related concepts, namely launch, innovation adoption, and diffusion are also employed in this study as appropriate; their different nuances of meaning are noted.

\section{METHODOLOGY}




\subsection{Gathering relevant articles}

As the research aim was to identify and analyze how the extant research articles linked networks and commercialization, the first stage in addressing the aim was to identify and collect as many relevant research articles as possible on commercialization networks; i.e. articles which linked networks to commercialization, launch, diffusion, and adoption. It became clear early in the preliminary searches that restricting the search to the most established journals or to journals representing particular disciplines might not fully capture the relevant research articles as the phenomenon is still emergent and vague. Therefore, although journal rankings are often employed as a proxy for quality and research impact (Singh, Haddad, \& Chow, 2007; Van Fleet, McWilliams, \& Siegel, 2000), we did not place specific emphasis on them. Instead, we emphasized representation across the disciplines. We selected the multidisciplinary EBSCO Business Source database as it covers a wide range of good quality journals in the field of technology and innovation management, marketing, and management, and includes recent research also from all geographic locations. For example, Web of Science excludes many European journals that we considered significant in this context as preliminary searches suggested that the research theme had emerged in these journals.

We started with a systematic search on all articles in which the title, keywords, or abstract mentioned the keywords "commercialization", "adoption", “diffusion", or "launch", in conjunction with "network" (searched as net*). The combined keywords commercialization and network were the most useful in sourcing the relevant articles, and keyword diffusion was the most challenging as it produced thousands of results, most of which were irrelevant to our particular research focus. Employing a database meant that we had to filter an extensive number of hits, so we decided to concentrate on those in which the Thesaurus terms of the database indicated relevance. Appendix 1 shows the number of articles identified through each search term combination. It should be noted that one article might be linked to several keywords. The whole search produced 883 articles. 


\subsection{Analyzing the identified articles}

The next step was to eliminate articles in which the focal phenomenon did not sufficiently represent our focus, networks for commercialization. First we read the abstract, and if it was still not clear whether the article focused on our theme, we skimmed through the article. A considerable number of articles that were ultimately excluded concerned diffusion regarding a particular population and innovation policy, or discussed commercialization at the macro level, instead of focusing on networking for commercialization per se. If commercialization and networks were linked and discussed briefly with regard to the defined focus, even if not at the core of the study, the article was included in the analysis. Articles concerning adoption/diffusion were excluded if they were not linked to networking for commercialization or the market performance of an innovation. We focused on research articles and thus excluded, for example, book reviews and editorials. All of these decisions were made through comparisons by three researchers. As result of these eliminations, 81 research articles were selected as shown in Table 2. The full citations of these articles are listed in Appendix 2.

\section{INSERT TABLE 2 HERE}

We conducted a systematic content analysis of these 81 articles. Content analysis is an established method that enables minimal interference by the researcher on the phenomenon studied, and enables large volumes of data to be handled (Krippendorff, 1980). The method enables the employment of both quantitative and qualitative textual analysis (Weber, 1985). We first read through the articles to acquire a general perspective on the focal research, and then compared, categorized, and coded the contents of the articles in terms of the following:

1. Classification of the forum (i.e., the journal and its disciplinary orientation) 
2. Identification of key terms concerning the phenomenon

3. Classification of innovation (i.e., type and nature of innovation or new product: e.g., incremental or radical, product or service) and its context (geographic and industrial)

4. Classification of commercialization perspective (e.g., commercialization, launch, and innovation adoption and diffusion aspects and tasks)

5. Classification of employed network approach and discussed network actors

6. Classification of the research methods and design

7. Identification of key findings on the contribution of the network actors to commercialization

Three business researchers participated in the data interpretation and categorization: one with a perspective on commercialization, one with an innovation-management perspective, and one with a perspective on network approaches. Knowledge of all these research streams was needed throughout the search and analysis process; for example, decisions relating to categorization and limitations were made by all three researchers together. The aspiration of the analysis was to identify multiple ideal types of network actor and their contribution to commercialization (see Doty \& Glick, 1994). Coding procedures and categories were assessed in detail by the researchers together, and compiled accurately. Excel tabling was employed to ensure a consistent detailed categorization, and interpretations of the research findings and key content of articles were compared. Some aspects were discussed with experienced network researchers to ensure the consistency and validity of the analysis. Consequently, researcher triangulation increased the trustworthiness of the findings.

\section{FINDINGS ON NETWORKS FOR COMMERCIALIZATION}




\subsection{The emergence of the network approach to commercialization within research}

The analysis showed that research on the topic is growing swiftly. The first article that focused clearly on networks for commercialization was published in 1992, with the emphasis on technology networking and strategic alliances. Few studies on commercialization network issues were published between 1992 and 2001; however, the topic began to appear in 2003. 80 percent of all articles focusing on networks for commercialization were published more recently, namely, 2007-2012. This highlights the fact that, although companies and researchers are beginning to pay more attention to the link between commercialization and networks, the research focusing on this area is still emergent.

Our analysis also recognized the multidisciplinary nature of the phenomenon; there was a considerable variety of disciplines from marketing to engineering and planning within which networks for commercialization were discussed. Table 3 presents the main disciplines, their focus on the phenomenon, and the key forums of the identified articles. Many articles on networks for commercialization have been published by Industrial Marketing Management and the Journal of Business Research, in the field of marketing, and The Journal of Product Innovation Management and Technovation, in the field of innovation management.

\section{INSERT TABLE 3 HERE}

Even though the research on innovation commercialization networks is still emergent, the number of authors contributing to the research stream is surprisingly large. The studied articles were produced by a total of 178 different researchers, an average of 2.2 per article. Most authors were affiliated to European universities (particularly in the UK, Denmark, Finland and Switzerland). 


\subsection{Innovations, innovation contexts, and methodological approaches linked to research on networks for commercialization}

The analysis indicated that the vast majority $(85 \%)$ of the articles concentrated on incremental innovations or did not specify the degree of novelty, which we assumed implicitly to mean incremental innovations, as radical innovations are exceptional. Radical innovations can, however, create such substantial competitive advantages and profit margins that it is unsurprising they evoke special interest among researchers. Commercialization of radical innovations was discussed in up to 15 percent of the articles.

The innovation types were also analyzed. Product innovations (e.g., CD players and pharmaceuticals) are explicitly present in 33 percent and technology innovations (e.g., biotechnology and environmental technologies) in 24 percent of the articles, together representing a majority of the articles. Conversely, service innovations (e.g., mobile and computer services) were discussed in 9 percent and system innovations (e.g., banking and telecommunications) in 12 percent of the articles, thus being quite seldom contemplated. Of the service innovation articles, all except one were published since 2009, indicating the increasing interest in the service sector. In 22 percent of the articles, the type of innovation was not specified.

Innovation target markets are more equally distributed. 38 percent of the articles focused on b-to-b innovations, 28 percent on b-to-c innovations, and the remaining 34 percent did not specify the target market. 74 percent of the articles focused on specific industry sectors; of those, almost half concentrated on the IT and electronics sectors. Regarding other industries, almost $20 \%$ of the articles specified pharmaceuticals and biotechnology.

Most articles (38\%) focused on European firms, with the UK clearly predominant, followed by firms from North America (24\%). The market scope of the innovator firms was not clearly defined in 33 percent of the articles. However, the market was identified as national in 34 percent, regional in six percent (usually the EU), and global in 27 percent of the articles. 
The analysis of the methods employed showed that 20 percent of the studies were conceptual, 55 percent were empirical based on primary data, and 25 percent being empirical relying on secondary data. It is noteworthy that only one of the 65 empirical studies explicitly relied on longitudinal data. Of the studies based on primary data, 62 percent utilized qualitative data (typically case studies with data collected mainly through interviews), 27 percent employed quantitative data (usually surveys), and 11 percent collected both. The studies relying on empirical secondary data were equally distributed between quantitative and qualitative data utilization.

With regard to methods, it is worth noting that the current research in most of the cases gathered data and analyzed them only from the innovator firm's perspective, almost always excluding other perspectives (e.g., complementaries; distributors; non-profit organizations).

\subsection{Theoretical approaches and key terms applied to networks for commercialization}

As the articles linking commercialization and networks were drawn from divergent disciplines, multiple theoretical network approaches were linked to commercialization. Table 4 incorporates the identified network approaches to commercialization, their emphasis on and conceptualizations for "networks for commercialization". Some articles explicitly stated their theoretical backgrounds and approach. Of those articles that did not, the approach was tracked by examining the employed references. In eight articles the followed approaches remained unsolved.

\section{INSERT TABLE 4 HERE}

It is striking that many articles employed several network approaches implicitly or explicitly; they combined mostly strategic, innovation, social and entrepreneur networks, and network economics approaches. Interorganizational network approaches (in particular, strategic network), focusing on organizations' relations, and social network approaches, focusing on key individuals' impacts, were 
those most often employed in addition to the network economics approach that discussed relations between political actors, other stakeholders, and industry actors. Research articles focusing on the role of social networks have paid more attention to adoption/diffusion and made relatively limited reference to commercialization perspectives. However, there were a few articles that touched on the role of users' social networks in commercialization efforts. The lack of research focusing on the employment of social networks for commercialization tasks might potentially evidence a disconnection between commercialization and adoption/diffusion research. Nonetheless, most research articles on adoption begin by referring to commercialization and innovation success challenges. Surprisingly, the innovation network approach did not stand out in particular, even though innovation management journals published the largest number of the reviewed studies. Entrepreneur network approach discussed networking and partnering with regard to new ventures, their growth and internationalization. Network organization approach focused either on internal or interoganizational teams and projects that facilitate commercialization. The Actor-Network Theory (ANT) approach was adopted infrequently, employed in only two studies.

When analyzing the linkages between the employed network approaches and disciplines, we noticed that the industrial marketing and strategic network research emphasizes business networks and collaboration between different companies for commercialization, and how such collaboration can be induced and organized. The entrepreneurship network approaches were employed to emphasize the management of the firm and its relations for commercialization, from the perspective of the focal company/entrepreneur. Innovation management and engineering research employed different network approaches to highlight that development and management of innovation might also require resources from external contributors over the innovation process. The social network approach employed in particular by innovation management and marketing studies suggests that successful commercialization requires innovation-promoting interaction and communication between individuals and communities. Network research with a more societal, political, or macro perspective 
(such as ANT and network economics) indicates that the whole society consolidates or diminishes the future of an innovation.

The analysis of the articles also captured contemporary terminology and revealed the diversity of terms linked to "networks for commercialization". No predominant single key term was identified; instead, more than 20 conceptualizations were captured and listed in Table 4. According to the reviewed articles, the networks comprised:

- Individuals (e.g., users; experts; managers; entrepreneurs)

- Groups (i.e., collaborative communities; peer communities; sub networks)

- Organizations (e.g., firms; associations; universities)

These entities were labeled network members, actors, players, stakeholders, partners, contributors, and supporters. The divergent terms reflect the perspectives of different disciplines on innovation management issues in general; however, they also both enrich and confuse the definitions and terminology concerning the core phenomenon.

The synthesis of key concepts and network approaches not only describes contemporary terminology but also indicates the various actors that might contribute to commercialization. For example, user/peer/opinion leader networks comprise individuals, and informal communities and groups that contribute through social networks, whereas partner organizations discussed within the interorganizational network, strategic network, and entrepreneur network literature emphasize how distributors, complementaries, and non-profit organizations can facilitate operational tasks or strategic planning in commercialization through collaboration. These network members and their contribution to commercialization is therefore discussed in more detail.

\subsection{Identified network actors and their contribution potential to commercialization}

Analysis of the research articles indicated how divergent network actors/members such as customers and users, distributors, complementaries, competitors, universities, government agencies, 
and associations (see Table 5) can contribute to commercialization.

\section{INSERT TABLE 5 HERE}

Actors such as individual users who form user networks or communities of peers can contribute intentionally or unintentionally to commercialization. According to the literature analysis, the social network approach in particular, which discusses innovation adoption and diffusion, examines the relevance of specific individuals in innovation success; these lead users, expert opinion leaders, and hub persons (with large numbers of contacts) have a substantial influence on opinion formation/change. These types of key person contribute by demonstrating a new product to other potential users, by explaining its unique benefits compared to what is currently available, functioning as lead teachers to followers, and acting as references (e.g., Goldenberg, Han, Lehmann, \& Hong, 2009; Harrison \& Waluszewski, 2008; Hienerth \& Lettl, 2011). Users also build an impression of a “critical mass" of adopters that often impacts others' adoption decisions and adoption intensity, and increases diffusion in terms of speed and extension (Van Siyke, Ilie, Hau Lou, \& Stafford, 2007). Such user mass is crucial, particularly for systemic innovation.

At the organizational level, divergent firms, public organizations, and associations can contribute to the success of commercialization. Distributors are crucial as they make the product available to users (e.g., Perks \& Moxey, 2011). Producers of complementaries, and even competitors, are potential sources of strategic collaboration that can fortify demand for a new product (e.g., MolinaCastillo, Munuera-Alemán, \& Calantone, 2011; Snow, Fjeldstad, Lettl, \& Miles, 2011). Public organizations and educational institutions can contribute to commercialization by, for example, envisioning the use of an innovation in society (e.g., Troshani \& Hill, 2009). Universities can establish trust and expertise due to their expert status (e.g., Inganäs, Harder, \& Marxt, 2007); it was notable that the articles which emphasized the role of universities as network actors tended to focus 
on the biotech sector. Political authorities can provide information within their own areas of expertise and facilitate the development of new business fields (e.g., Inganäs et al., 2007; Tolfree, 2008). Firms with supplementary resources (e.g., consultants; advertising agencies) fortify and upgrade innovator firms' commercialization activities (e.g., Story et al., 2009). Investors provide financial resources for commercialization, and also enable further networking (e.g., Pittaway, Robertson, Munir, Denyer, \& Neely, 2004). Established firms with high profile names acting as partners and supporters can also play an important role throughout the commercialization process as their stability, credibility, and good reputation often spread to their partners and establish the credibility of new ventures in particular (see e.g., Tolstoy \& Agndal, 2010). Based on the reviewed articles, associations and public organizations constitute knowledge brokers which disseminate information, and establish expertise and credibility (e.g., Aarikka-Stenroos \& Sandberg, 2012; Troshani \& Hill, 2009).

In comparing studies on radical and incremental innovations it became clear that similar kinds of diversity in network actors were prevalent in both. Convincing other actors to support the commercialization of radical innovations is particularly demanding, as they are extremely cautious in supporting an innovation that might endanger their current market position and has no guarantee of achieving market success. However, the successful launch of radical innovations often requires complementary products and services, new kinds of infrastructure, and the significant readjustment of existing business; thereby making the participation of other actors not only helpful, but crucial (e.g., Chiesa \& Frattini, 2011).

\section{DISCUSSION}

This section summarizes and develops further the knowledge driven by the reviewed articles with regard to employed network approaches to commercialization, relevant network actors and their contribution to commercialization. 
The findings support the idea that divergent actors surrounding the innovator company impart knowledge, relations, and other resources that are important to commercialization, and facilitate commercialization in many ways. Figure 1 provides an integrative framework depicting network actors contributing to commercialization; the conceptual framework comprises all divergent relevant actors and typifies each actor's main contribution to commercialization derived from the literature review. It shows that not only business organizations but also informal and not-for-profit organizations, communities, and key individuals impact commercialization success. As findings on network actors showed, users' ability to disseminate information and educate other users, and complementaries' ability to create supporting offerings and increase credibility are discussed quite plausibly; however, distributors, whose role is often pivotal in making the innovation available to users, merit surprisingly little discussion.

\section{INSERT FIGURE 1 HERE}

We emphasize that, although the framework depicts actors and their contributions in a simplified manner because the network is presented as a portfolio of relationships, our findings also reveal the phenomenon to be more complicated. Actors often are interconnected with each other, thereby turning portfolios into mutual relationships and interactive networks that influence the dynamics of the network. On network level, actors can for example collaborate horizontally or vertically within different network constellations. Moreover, the actors have direct and indirect relationships (e.g., distributors and the media provide indirect relations to customers) that also complicate the contributions. Furthermore, the contributions occur at both organizational and personal levels. Consequently, personal and organizational contributions can overlap; for example, members of professional associations are persons who through their organizations are involved in business networks and, as boundary spanners, are able to impart further knowledge that is important to the 
diffusion of a product or technology. Moreover, each actor can bring forward several contributions, while some can be introduced by several actors (i.e., credibility can be enhanced by, for example, universities and associations). Actors can contribute intentionally or unintentionally and directly or indirectly. For example, policy makers and complementaries can intentionally promote the creation and development of a particular industry, although their contribution is intended to strengthen the industry or a product category as a whole, rather than a specific product or the business of an individual firm. However, their activities indirectly and unintentionally contribute also to an individual firm's innovation business and further commercialization. As our thinking perceives that an innovator firm can intentionally develop and orchestrate its network relations, our framework depicts actors with whom the innovator firm could engage and collaborate for commercialization. Moreover, we think that divergent actors' potential contributions to commercialization provide the reasons that might motivate innovation firms to engage with and develop relations with such contributors. Moreover, the analysis suggests that the interaction with network actors enhances learning in markets with regard to commercialization: the firm may realize what aspects are relevant to end users, distributors, and society and how to initiate entry to markets and interact with potential customers and other stakeholders.

We also clustered the contributors and outlined their key contribution types and modes. As our objective was to identify multiple ideal types for network actors' contribution to commercialization, and to develop an integrative typology rather than a taxonomy of mutually exclusive categories (see Doty \& Glick, 1994), some types might partly overlap.

\section{INSERT FIGURE 2 HERE}

Our analysis indicates that divergent network actors make three types of key contributions to commercialization, itself a long and multilateral process (see Figure 2). First, some network actors 
create markets for innovations; for example, related firms and other organizations collaborate proactively and strategically to prompt the emergence of new business fields. Regulators, investors, public organizations, the media, complementaries, suppliers, and manufacturers together shape markets by breeding ecosystems that enable the birth and growth of new business. Such collaboration does not support directly an individual product or company but builds grounds for commercialization per se. Research investigating how markets are created to commercialize new products has focused on interorganizational relations and clusters, and employed strategic network, entrepreneur network, and network economics approaches.

Second, all adopters and users as well as media, distributors and many other organizations facilitate and accelerate further adoption in markets by impacting attitudes and choices, and by creating the influence of critical mass. Research investigating a focus on this aspect, for instance, how networked adopters and users impact further adoption, has employed social network, ANT, and network economics approaches.

Third, some network actors can directly perform practical commercialization tasks that are crucial to the focal innovator company and the innovation: users, the media, and divergent organizations and communities inform and educate other actors and markets on the employment and benefits of the innovation; distributors deliver innovations; investors provide financial resources; and related companies conduct tactical co-marketing and/or increase the attractiveness of an innovation with offerings that turn isolated products and services into comprehensive solutions. Research investigating how relationships and networks of innovator firm(s) are created and employed for practical commercialization tasks has utilized industrial network, innovation network, user network, entrepreneur network, and network organization approaches.

We also propose a model (see Figure 3) that comprises four basic modes of contribution. These modes are characterized as a function of two vectors acting as a continuum. One of the vectors reflects the intentionality of the contribution to the commercialization, while the other relates to how 
directly the actors contribute. Partners (e.g., distributors and complementaries) intentionally and directly provide resources and perform commercialization tasks through close and intentional cooperation; intentional promoters (e.g., associations and public organizations) can be indirectly engaged to support diffusion, market creation, or industry development through close cooperation; unintentional promoters (e.g., expert opinion leaders on the focal industry) contribute commercialization tasks distantly; facilitators (e.g., regulators) indirectly and distantly support diffusion, market creation, or industry development by shaping the market environment.

Noteworthy is that as one actor can offer several contribution types through diverse modes and also the innovation context impacts the relevance of different actors, the compositions may vary depending on contextual features.

\section{INSERT FIGURE 3 HERE}

Identification of the key contributions types and modes can also reduce conceptual fuzziness on the phenomenon: "commercialization networks", "collaboration for commercialization", and "adoption networks" are employed as synonyms referring to "networked actors involved in commercialization"; however, they often have clearly different meanings. For example, commercialization network emphasizes the innovators' perspectives and the innovator firm's intentional activities in motivating and committing potential actors, whereas adoption network highlights the macro level and customers' and other stakeholders' perceptions and actions that direct the innovation through acceptance.

The analysis also emphasized the firm's ability to employ relations for commercialization. The size and novelty of the innovator firms reflects their potential to attract various kinds of contributor; as such, a small firm can encounter insurmountable obstacles when approaching prospective contributors (Aarikka-Stenroos \& Sandberg, 2012). The reviewed articles indicated that firms producing radical innovations have usually needed to establish complex networks for research and 
development (e.g., Harryson, Dudkowski, \& Stern, 2008; Tidd, 1995; Story, O’Malley, \& Hart, 2011) and presumably already possessed advanced network capabilities when commencing commercialization. Such capabilities are of paramount importance as reviewed articles showed that, unlike incremental innovations for which networks often develop incrementally over time alongside growing trust and commitment (e.g., Stuart, Ozdemir, \& Ding, 2007; Van de Ven, 2005), networks are more likely to be created, abandoned, and remobilized swiftly for radical innovations (e.g., Story et al., 2009).

Innovator firms might adopt different profiles in relation to utilizing identified contributors with different types and modes of contribution. For instance, some firms seem to focus on particular contributors and modes of contribution, such as solely partnering (e.g., Wince-Smith, 1993), whereas others strive to attain a large variety of contributors with diversified contributions. The analyzed case studies in particular offer exemplars on how to employ these commercialization contributors, and what kinds of implication such employment can offer. For example, building a user network can turn a previously failed product launch into a success, as happened with a Biacore biosensor product; however, this required systematic identification and interaction with multiple potential lead-users, and facilitation of user-to-user interaction (see Harrison \& Walusewski, 2008). According to Chiesa and Frattini's research (2011), crucial support can be acquired through the early building of longterm partnerships with critical actors, and out-licensing the technology both to competitors and complementaries. For example, the firm developing Tom Tom GO navigator networked early with Tele Atlas for the provision of digital maps and the US Department of Defense as it regulated the access to GPS satellites, both partners securing crucial features for the innovation. In addition, the three diverse types of lead-user had strongly positive attitudes concerning the innovation. Johnson (2008) shows the contributive role of a government actor in a triple helix network by reporting on an industry-led consortium, Precarn, which from the small innovator firm's perspective helps to gather the network actors needed for commercialization, and organizes a pre-commercial project. In such a 
project, one party must be capable of commercializing the technology while other partners typically play the roles of a technology user (i.e., organize tests; be the first customer), scientific partners, and other technology developers. Through this pre-commercial project, expertise can be pooled, risks and costs shared, development accelerated, and the research-industry gap bridged; in addition, the consortium directly contributes to the creation of new industries.

\section{CONCLUSIONS AND IMPLICATIONS}

\subsection{Theoretical implications and contributions}

Commercialization and how it is managed through networks is an emergent issue that interests both practitioners and researchers across a range of business, engineering, and management disciplines. By reviewing the extant research on networks for commercialization, this study generates new knowledge on how innovator firms can employ networks to ensure the successful commercialization of new products. This study focuses explicitly on commercialization, and thus it extends research on networking for innovation that has mostly focused on R\&D (e.g., Dhanaraj \& Parkhe, 2006; Gulati 2000). Through a structured literature review, the study analyzes how different network approaches are applied to commercialization, identifies relevant network actors in terms of commercialization, and develops an integrative conceptual framework depicting how network actors contribute to commercialization. First, the key contribution lays in the analysis of divergent network actors (i.e., individuals; groups; organizations) and their potential input to commercialization, and in the development of an integrative framework that captures the main contributions of network actors to commercialization. The review highlights that not only customers and users but also lead partners, such as distributors, complementaries, public organizations, regulators, and opinion leaders, can contribute to commercialization in three ways by creating markets, performing commercialization tasks, and facilitating innovation adoption/diffusion (i.e. types of contribution). Such actors prepare 
markets for an innovation and amend strategic planning, build credibility, ensure the delivery and existence of supportive complementary offerings, mobilize user communities to ensure market pull effects and improve customer education, to enable innovations to thrive in a supportive environment. We also identify different modes of contribution; from the focal firm's perspective, network actors can intentionally or unintentionally and directly or indirectly support the commercialization of innovations. Moreover, our review indicates that both incremental and radical innovations need help from diverse network actors; however, support from the network itself is even more crucial for the latter.

Second, we contribute by identifying and comparing different conceptualizations and foci of divergent network approaches that researchers in various disciplines have applied to the analysis of networks for commercialization to date, and in analyzing their implications. Due to its extensive approach, this review concludes that the interdisciplinary topic of innovation becomes increasingly interdisciplinary as the social and organizational interaction with and between divergent stakeholders becomes denser when an innovation faces markets at commercialization. Extensive cross-disciplinary analysis shows how each network approach reveals an interesting dimension of the phenomenon. For example, the strategic network approach emphasizes the competitive advantage of networking for commercialization, whereas industrial networking research improves our understanding on how interactive relationships for commercialization can be built. Social network and ANT research highlights how networked entities (i.e., individuals; groups; organizations; technologies) shape a macro system, an ecosystem. The entrepreneur network literature emphasizes how small innovator firms augment their scarce resources for commercialization through networking.

The systematic analysis of current research, however, shows that there is a need to develop coherent conceptualizations especially concerning network approaches and commercialization, and to accumulate the current knowledge that would strengthen the theoretical basis of this research field. Our integrative analysis facilitates the development of a more coherent theorization and terminology 
for networks and collaboration for commercialization. Vagueness in the employment of concepts is typical to new research areas that lay at the intersection of various research streams. Researchers are therefore encouraged to provide clear definitions of terms so as not to complicate further this interdisciplinary field. Our analysis also reveals several research gaps that are proposed as topics for further research.

\subsection{Implications for divergent stakeholders/network actors: researchers, managers, and politicians}

The findings prompt implications for divergent stakeholders. First, this study calls for researchers to focus their attention also on networks for commercialization, instead of studying only research and development networks.

Innovative companies are encouraged to identify and motivate relevant actors for commercialization. The identification of contributors requires understanding on the potential supporters' perspectives on innovation diffusion/adoption and their goals, and to find ways of involving them in commercialization. In particular, our findings on commercialization actors and their contribution potential (see Table 5; Figure 1; Figure 2; Figure 3) will help innovator firms and new product developers identify relevant actors. The typologies of network contributors facilitate the identification of a firm's contributors, or those for which it strives. Mapping commercialization contributors, contributions, types and modes will help managers consider what kind of support they can expect from contributors, and what compensation contributors will expect in return. Firms can realize the full potential of actors in their existing networks and, when needed, purposefully develop new networks for commercialization. In addition to organizational actors from distributors to investors and complementaries, personal network actors such as opinion leaders and key users, and non-profit organizations' resources can promote an innovation. Although the input of potential network actors can be extensive, their mobilization to promote an innovation can be problematic. 
Management issues and a lack of trust are typical of commercialization (see Aarikka-Stenroos \& Sandberg, 2012; Heikkinen, Mainela, Still, \& Tähtinen, 2007), and the actors' perspective on the nature, extent, and length of a jointly decided action can vary across the commercialization network (e.g., Mouzas and Naudé, 2007), which can in turn also complicate the employment of networks for commercialization. All companies are encouraged to acknowledge that they can better reach their goals by supporting an innovation, and encouraged to differentiate competitive advantage by cocreating value with innovative co-offerings. Through collaboration with innovative companies, they can offer complete solutions rather than isolated products.

Politicians and governmental actors are encouraged to realize that the commercialization of innovations requires resources but is crucial for society, and that successful commercialization often requires collaboration with various kinds of company and organization. These actors can facilitate firms' commercialization efforts, not only with financial resources but also by offering communication and networking support. It is challenging for a single and, in particular, a small innovative company to induce and activate networking, and therefore political deeds and strategic joint ventures are required.

\subsection{An agenda for further research}

The literature review revealed several gaps that are suggested as potential future research topics in the research agenda (see Table 6). As multiple network actors are able to impact the success of innovation throughout the long multidimensional commercialization process via divergent means, the topic clearly requires investigation from different perspectives of relevant network actors in markets over a long time span.

\section{INSERT TABLE 6 HERE}


Our analysis indicates that a holistic understanding involving the examination of all involved actors' perspectives on networks for commercialization is often missing, so researchers should investigate the perspectives of divergent network actors with contribution potential. This can also enhance the building of knowledge on how an innovator firm can mobilize and commit potential actors. In turn, this will link to discussions on the management of divergent relations for commercialization and network actor mobilization. In the reviewed articles, the management of business relations for commercialization in particular was highlighted as a pivotal topic. Therefore, the question is how can commercialization networks including diverse actors be orchestrated at an industry level or managed by the innovator firm in a network to grasp their contribution potential. In particular, unintentional and indirect contributions to commercialization by users, complementaries, policy makers, and other market actors can be crucial, although difficult to manage. Research on this area will also bridge the identified gap between commercialization and adoption and diffusion studies.

Moreover, the longitudinal aspect on the topic was missing. With regard to the commercialization theme, the process and its change over time are pertinent. We therefore call for future research with longitudinal designs to address the evolution of the commercialization network. In addition, the dynamics of commercialization networks merit more research but such research goals cannot be accomplished without longitudinal research designs.

It would also be beneficial to extend the current knowledge by investigating different innovation contexts and also including related research on alliances or stakeholders to provide a more accurate picture of the phenomenon.

Our analysis reveals that some particular actors tend to be relevant although they have been neglected by research. Even though distributors often occupy a key position in making an innovation available to users, their role in commercialization is unexplored. Also, divergent non-profit actors with extensive contribution potential to commercialization merit more research. 
We believe that further research inputs to these topics can show how innovations truly are developed and established in networked markets.

\subsection{Limitations of the paper}

There are some limitations to our paper. Due to limited resources, our study covers one multidisciplinary database. However, we believe that the chosen extensive database provides a comprehensive depiction of the current state of commercialization network research, and the inclusion of other databases would probably not have radically changed this picture. We also focused on the conceptualization "network" and excluded the terms "alliance" and "stakeholders". We acknowledge that the content analysis of the relevant articles was subjective in certain respects; for example, as many researchers did not position their work, we employed implicit and explicit cues to position their research, which might be positioned differently by the respective authors themselves. However, researcher triangulation and explicit coding rules increased the trustworthiness of the results. Despite these limitations, this review provides managers and researchers with a better understanding on the current and rapidly evolving field of commercialization network research. 


\section{References}

Aarikka-Stenroos, L. \& Lehtimäki, T. (2013). Building up a firm's commercialisation competence: from product concept to the first reference. International Journal of Technology Marketing, 8, 2, $177-196$

Aarikka-Stenroos, L., \& Sandberg, B. (2012). From new-product development to commercialization through networks. Journal of Business Research, 65, 2, 198-206.

Aldrich H., \& Zimmer, C. (1986). Entrepreneurship through social networks. In D.L. Sexton, R.W. Smilor (Eds.), The Art and Science of Entrepreneurship (p. 3-23). Ballinger Publishing, Cambridge, MA,

Araujo, L., \& Easton, G. (1996). Networks in socioeconomic systems. A critical review. In D., Iacobucci (Ed.), Networks in Marketing (pp. 63-107). Thousand Oaks: Sage Publications.

Bercovitz, J., \& Feldman, M. (2011). The mechanisms of collaboration in inventive teams: Composition, social networks, and geography. Research Policy, 40, 1, 81-93.

Bohlmann, J. D.; Calantone, R. J. \& Meng Zhao (2010). The effects of market network heterogeneity on innovation diffusion: An Agent-based modeling approach. Journal of Product Innovation Management, 27, 5, 741-760.

Burt, R.S. (1992). Structural holes: The Social structure of competition. Cambridge, MA: Harvard University Press.

Chakravorti, B. (2004). The new rules bringing innovations to market. Harvard Business Review, March 2004, 59-67.

Chiesa, V., \& Frattini, F. (2011). Commercializing Technological Innovation: Learning from Failures in High-Tech Markets. Journal of Product Innovation Management, 28, 4, 437-454.

Christensen, C. M. (1992). Exploring the limits of the technology s-curve. Part I Component technologies. Production and Operations Management, 1, 4, 334-357. 
Coviello, N. \& Munro, H. (1995). Growing the entrepreneurial firm: networking for international market development, European Journal of Marketing, 29, 7, 49-61.

Crawford, M., \& Di Benedetto, A. (2008). New products management. (9 $9^{\text {th }}$ ed.). New York: McGraw-Hill.

Danov, M. A., Smith, J. B. \& Mitchell, R. K. (2003). Relationship prioritization for technology commercialization. Journal of Marketing Theory \& Practice, 11, 3, 59-70.

de Reuver, M. \& Bouwman, H. (2012). Governance mechanisms for mobile service innovation in value networks. Journal of Business Research, 65, 3, 347-354

Dhanarag, C., \& Parkhe, A. (2006). Orchestrating innovation networks. Academic Management Review, 31, 3, 659-669.

Di Benedetto, C. A. (1999). Identifying the key success factors in new product launch. Journal of Product Innovation Management, 16, 5, 530-544.

Doty, D. H., \& Glick, W. (1994). Typologies as a unique form of theory building. The Academy of Management Review, 19, 2, 230-251.

Easingwood, C., Moxey, S., \& Capleton, H. (2006). Bringing high technology to market: Successful strategies employed in the worldwide software industry. Journal of Product Innovation Management, 23, 6, 498-511.

Freeman, S., Hutchings, K., Lazaris, M. \& Zyngier, S. (2010). A model of rapid knowledge development: The smaller born-global firm. International Business Review, 19, 1, 70-84.

Garcia, R., \& Calantone, R. (2002). A critical look at technological innovation typology and innovativeness terminology: a literature review. Journal of Product Innovation Management, 19, 2, 110-132.

Goldenberg, J., Han, S., Lehmann, D. \& Hong, J. W. (2009). The Role of hubs in the adoption process. Journal of Marketing, 73, 2, 1-13. 
Granovetter, M. (1973). The Strength of weak ties. American Journal of Sociology, 78, 6, 1360-1380

Gulati, R. (1998). Networks and alliances. Strategic Management Journal, 19, 4, 293-317.

Harrison, D., \& Waluszewski, A. (2008). The development of a user network as a way to re-launch an unwanted product. Research Policy, 37, 1, 115-130.

Harryson, S. J., Dudkowski, R. \& Stern, A. (2008). Transformation networks in innovation alliances - The development of Volvo C70. Journal of Management Studies, 45, 4, 745-773.

Harty, C (2010). Implementing innovation: designers, users and actor-networks. Technology Analysis \& Strategic Management, 22, 3, 297-315.

Heikkinen, M. T., Mainela, T., Still, J., \& Tähtinen, J. (2007). Roles for managing in mobile service development nets. Industrial Marketing Management, 36, 7, 909-925.

Hienerth, C., \& Lettl, C. (2011). Exploring how peer communities enable lead user innovations to become standard equipment in the industry: Community pull effects. Journal of Product Innovation Management, 28, 1, 175-195.

Håkansson, H. \& Ford D. (2002). How should companies interact in business networks? Journal of Business Research, 55, 2, 133-139

Inganäs, M., Harder, M., \& Marxt, C. (2007). Measuring the science-to-market gap. The case of new energy technologies. International Journal of Innovation \& Technology Management, 4, 4, 457478

Iyengar, R., Van den Bulte, C., Eichert, J., West, B., \& Valente, T. W. (2011). How social networks and opinion leaders affect the adoption of new products. GfK-Marketing Intelligence Review, 3, $1,16-25$.

Jarillo, J. C. (2006). On strategic networks. Strategic Management Journal, 9, 1, 31-41.

Johanson, J. \& Vahlne, J.-E. (2009). The Uppsala internationalization process model revisited: From liability of foreignness to liability of outsidership. Journal of International Business Studies, 40, 
1411-1431.

Jolly, V. K. (1997). Commercializing new technologies. Getting form mind to market. Boston, MA: Harvard Business School Press.

Katz, M. L. \& Shapiro C. (1985). Network externalities, competition, and compatibility. The American Economic Review, 75, 3, 424-440.

Kogut, B. (2000). The network as knowledge: Generative rules and the emergence of structure. Strategic Management Journal, 21, 3, 405-425.

Krippendorff, K. (1980). Content analysis: An introduction to its methodology. Beverly Hills, CA: Sage Publications.

Latour, B. (2005). Reassembling the social - An introduction to Actor-Network-Theory. Oxford University Press.

Law, J. (1992). Notes on the theory of the actor-network: Ordering, strategy, and heterogeneity. Systems Practice, 5, 4, 379-393.

Lettl, C., Hienerth, C., \& Gemuenden, H., (2007). Exploring how lead users develop radical innovation: Opportunity recognition and exploitation in the field of medical equipment Technology. IEEE Transactions on Engineering Management, 55, 2, 219-233.

Mohr, J. (2001). Marketing of High-Technology Products and Innovations. Upper Saddle River, New Jersey: Prentice Hall.

Molina-Castillo, F-J., Munuera-Alemán, J-L., \& Calantone, R. J. (2011). Product quality and new product performance: The role of network externalities and switching costs. Journal of Product Innovation Management, 28, 6, 915-929.

More, R. A. (1983). Overcoming barriers to the adoption of high technology in industrial markets. Business Quarterly, 48, 4, 110-117.

Mouzas, S., \& Naudé, P. (2007). "Network mobilizer", Journal of Business \& Industrial Marketing, 
$22,1,62-71$.

Mu, J. \& Di Benedetto, C. A. (2011) Strategic orientations and new product commercialization: mediator, moderator, and interplay. $R \& D$ Management, 41, 4, 337-359.

Möller, K., \& Svahn, S. (2009). How to influence the birth of new success fields - Network perspective. Industrial Marketing Management, 38, 4, 450-458.

Möller, K., and Rajala, A. (2007). Rise of strategic nets - New modes of value creation. Industrial Marketing Management, 36, 895-908.

Partanen, J., Chetty, S. K., \& Rajala, A. (2011). Innovation types and network relationships. Entrepreneurship Theory and Practice, May, 1-29.

Perks, H., \& Moxey, S. (2001). Market-facing innovation networks: How lead firms partition tasks, share resources and develop capabilities. Industrial Marketing Management, 40, 8, 1224-1237.

Pittaway, L., Robertson, M., Munir, K., Denyer, D., \& Neely, A. (2004). Networking and innovation: a systematic review of the evidence. International Journal of Management Reviews, 5/6, 3/4, 137-168.

Powell, W., White, D., Koput, K. \& Owen-Smith, J. (2005) Network dynamics and field evolution: The Growth of interorganizational collaboration in the life sciences. American Journal of Sociology, 110, 4, 1132-1205.

Prebble, D. R., de Wall, G. A. \& de Groot, C. (2008). Applying multiple perspectives to the design of a commercialisation process. $R \& D$ Management, 38(3) 311-320.

Prenkert, F. (2012). Commentary to "From new-product-development to commercialization through networks”. Journal of Business Research, 65(2), 207-209.

Robertson, M., Swan, J. \& Newell, S. (1996). The role of networks in the diffusion of technological innovation. Journal of Management Studies, 33 3, 333-359.

Rogers, E. M. (1983). Diffusion of Innovations. (3rd ed.). New York, NY: The Free Press. 
Schumpeter, J. A. (1934). The Theory of Economic Development. An Inquiry into profits, capital, credit, interest, and the business cycle. Cambridge, MA: Harvard University Press.

Sillanpää, A., \& Laamanen, T. (2009). Positive and negative feedback effects in competition for dominance of network business systems. Research Policy, 38, 5, 871-884.

Singh, G., Haddad, K. M., \& Chow, C. W. (2007). Are articles in "top" management journals necessarily of higher quality? Journal of Management Inquiry, 16, 4, 319-331.

Snow, C. C., Fjeldstad, Ø. D., Lettl, C. \& Miles, R. E. (2011). Organizing continuous product development and commercialization: The collaborative community of firms' model. Journal of Product Innovation Management, 28, 1, 3-16.

Song, M., Parry, M. E. \& Kawakami, T. (2009). Incorporating network externalities into the technology acceptance model. Journal of Product Innovation Management, 26, 3, 291-307.

Story, V., Hart, S., \& O'Malley, L. (2009). Relational resources and competences for radical product innovation. Journal of Marketing Management, 25, 5/6, 461-481.

Story, V., O'Malley, L., \& Hart, S. (2011). Roles, role performance, and radical innovation competences. Industrial Marketing Management, 40, 6, 952-966.

Stuart, T. E.; Ozdemir, S. Z. \& Ding, W. W. (2007). Vertical alliance networks: The case of university-biotechnology-pharmaceutical alliance chains. Research Policy, 36, 4, 477-498.

Talke, K., \& Hultink, J. E. (2010). Managing Diffusion Barriers When Launching New Products. Journal of Product Innovation Management, 27, 4, 537-553.

Tidd, J. (1995). Development of novel products through intraorganizational and interorganizational networks. Journal of Product Innovation Management, 12, 4, 307-322.

Tolfree, D. (2008). Progress in commercialising micro-nanotechnology in the UK. International Journal of Technology Transfer \& Commercialisation, 7, 4, 284-289.

Tolstoy, D., \& Angdal, H. (2010). Network resource combinations in the international venturing of 
small biotech firms. Technovation, 30, 1, 24-36.

Torraco, R. J. (2005). Writing integrative literature reviews: Guidelines and examples. Human Resource Development Review, 4, 3, 356-367.

Troshani, I., \& Hill, S. R. (2009). Linking stakeholder salience with mobile services diffusion. International Journal of Mobile Communications, 7, 3, 269-289.

Uzzi, B. (1996). The Sources and consequences of embeddedness for the economic performance of organizations: The Network effect. American Sociological Review, 61, 4, 674-698

Van de Ven, A. H. (2005). Running in packs to develop knowledge-intensive technologies. MIS Quarterly, 29, 2, 365-377.

van Eck, P. S., Jager, W. \& Leeflang, P. S. H. (2011). Opinion leaders' role in innovation diffusion: A simulation study. Journal of Product Innovation Management, 28, 2, 187-203.

Van Fleet, D. D., McWilliams, A., \& Siegel, D. S. (2000). A Theoretical and Empirical Analysis of Journal Rankings: The Case of Formal Lists. Journal of Management, 26, 5, 839-861.

Van Siyke, C., Ilie, V., Hao Lou \& Stafford, T. (2007). Perceived critical mass and the adoption of a communication technology. Journal of Information Systems, 16, 3, 270-283.

Weber, R. (1985). Basic content analysis. Beverly Hills, CA: Sage Publications.

Wince-Smith, D (1993). Driving competitiveness through partnerships. Economic Development Quarterly, 7, 1, 12.

Vowles, N., Thirkell, P. \& Sinha, A. (2011). Different determinants at different times: B2B adoption of a radical innovation. Journal of Business Research, 64, 11, 1162-1168.

Wood, S. C. \& Brown, G. S. (1998). Commercializing nascent technology: The case of laser Diodes at Sony. Journal of Product Innovation Management, 15, 2, 167-183. 
Table 1 Diverse established network approaches

\begin{tabular}{|c|c|c|}
\hline Network approach & Characteristic & Key sources \\
\hline $\begin{array}{l}\text { The economics of } \\
\text { networks }\end{array}$ & $\begin{array}{l}\text { Focus on network effects and competition in the } \\
\text { network environment; network externalities }\end{array}$ & $\begin{array}{l}\text { e.g., Katz \& } \\
\text { Shapiro, } 1985\end{array}$ \\
\hline Entrepreneur networks & $\begin{array}{l}\text { Emphasis on small firms' networking for } \\
\text { resources, e.g., for growth and internationalization }\end{array}$ & $\begin{array}{l}\text { e.g., Aldrich \& } \\
\text { Zimmer, } 1986\end{array}$ \\
\hline Industrial networks & $\begin{array}{l}\text { Emphasis on interactive relationships between } \\
\text { networked companies; the basic assumption is that } \\
\text { networks cannot be managed }\end{array}$ & $\begin{array}{l}\text { e.g., Håkansson \& } \\
\text { Ford, } 2002\end{array}$ \\
\hline Innovation networks & $\begin{array}{l}\text { Emphasis on managing networked firms for R\&D } \\
\text { and innovation }\end{array}$ & $\begin{array}{l}\text { e.g., Dhanaraj \& } \\
\text { Parkhe, } 2006\end{array}$ \\
\hline Network theory & Focus on network dynamics & $\begin{array}{l}\text { e.g., Powell et al., } \\
2005\end{array}$ \\
\hline Social networks & $\begin{array}{l}\text { Focus on relationships of social entities, i.e., } \\
\text { individuals and organizations }\end{array}$ & $\begin{array}{l}\text { e.g., Granovetter, } \\
\text { 1973; Burt, 1992; } \\
\text { Uzzi, } 1996\end{array}$ \\
\hline Strategic networks & $\begin{array}{l}\text { The basic assumption being that networks of } \\
\text { companies can be managed towards a shared goal }\end{array}$ & $\begin{array}{l}\text { e.g., Jarillo, 2006; } \\
\text { Gulati, 1998; } \\
\text { Möller \& Svahn, } \\
2009\end{array}$ \\
\hline Actor networks & $\begin{array}{l}\text { Networks comprise the material and semiotic } \\
\text { relations between humans and non-human objects }\end{array}$ & $\begin{array}{l}\text { e.g., Latour, 2005; } \\
\text { Law, } 1992\end{array}$ \\
\hline
\end{tabular}


Table 2. The research stages: identification of articles, content analysis, and delimitations

\begin{tabular}{|l|c|}
\hline \multicolumn{1}{|c|}{ Search and analysis stages } & Result of the stage \\
\hline $\begin{array}{l}\text { The complete search with key concepts: commercialization, launch, } \\
\text { adoption or diffusion, and network. }\end{array}$ & 8874 articles \\
\hline Delimitations from the database thesaurus. & 883 articles \\
\hline $\begin{array}{l}\text { Content analysis on the basis of the abstract and further delimitations: } \\
\text { articles were chosen for further analysis. } 883 \text { abstracts were read by researchers and potentially relevant }\end{array}$ & 201 articles \\
\hline $\begin{array}{l}\text { Content analysis on the basis of article content and final delimitations: } \\
\text { all } 201 \text { articles were skimmed through by researchers and articles } \\
\text { discussing the research theme were included for detailed analysis. }\end{array}$ & 81 articles \\
\hline $\begin{array}{l}\text { Systematic content analysis for the final group of reviewed articles: } \\
\text { all } 81 \text { articles were analyzed and coded thoroughly by researchers. }\end{array}$ & 81 articles \\
\hline
\end{tabular}


Table 3. The multidisciplinary nature of the phenomenon: screening of the disciplines and forums for articles focusing on networks for commercialization.

\begin{tabular}{|c|c|c|c|}
\hline Discipline & $\begin{array}{c}\text { View on } \\
\text { commercialization }\end{array}$ & Example journals & $\begin{array}{c}\text { Number of } \\
\text { articles linking } \\
\text { networks and } \\
\text { commercializat } \\
\text { ion }\end{array}$ \\
\hline $\begin{array}{l}\text { Innovation } \\
\text { management } \\
\text { and technology }\end{array}$ & $\begin{array}{l}\text { Commercialization, } \\
\text { adoption, and diffusion } \\
\text { within innovation processes } \\
\text { and their management }\end{array}$ & $\begin{array}{l}\text { Journal of Product Innovation } \\
\text { Management; Technovation; } \\
\text { Research Policy; IEEE } \\
\text { Transactions on Engineering } \\
\text { Management }\end{array}$ & $\begin{array}{c}34 \\
42 \%\end{array}$ \\
\hline Marketing & $\begin{array}{l}\text { Marketing and market } \\
\text { creation of new products }\end{array}$ & $\begin{array}{l}\text { Industrial Marketing } \\
\text { Management; Journal of } \\
\text { Marketing; Journal of } \\
\text { Business Research; Journal of } \\
\text { Marketing Management }\end{array}$ & $\begin{array}{c}20 \\
25 \%\end{array}$ \\
\hline $\begin{array}{l}\text { Management } \\
\text { and } \\
\text { organization } \\
\text { studies }\end{array}$ & $\begin{array}{l}\text { Management of the firm in } \\
\text { R\&D and } \\
\text { commercialization }\end{array}$ & $\begin{array}{l}\text { Management Science; Journal } \\
\text { of Management Studies; } \\
\text { Organization Science and } \\
\text { Administrative Science } \\
\text { Quarterly }\end{array}$ & $\begin{array}{c}12 \\
15 \%\end{array}$ \\
\hline $\begin{array}{l}\text { Engineering, } \\
\text { information } \\
\text { systems }\end{array}$ & $\begin{array}{l}\text { Commercializing particular } \\
\text { technologies and products }\end{array}$ & $\begin{array}{l}\text { Journal of Management } \\
\text { Information Systems; MIS } \\
\text { Quarterly; International } \\
\text { Journal of Mobile } \\
\text { Communications }\end{array}$ & $\begin{array}{c}5 \\
6 \%\end{array}$ \\
\hline $\begin{array}{l}\text { Entrepreneur- } \\
\text { ship and } \\
\text { venturing }\end{array}$ & $\begin{array}{l}\text { Innovation firms and } \\
\text { entrepreneurship in } \\
\text { commercialization }\end{array}$ & $\begin{array}{l}\text { Journal of International } \\
\text { Entrepreneurship; } \\
\text { Entrepreneurship: Theory \& } \\
\text { Practice }\end{array}$ & $\begin{array}{c}3 \\
3,5 \%\end{array}$ \\
\hline $\begin{array}{l}\text { Policy and } \\
\text { Planning }\end{array}$ & $\begin{array}{l}\text { Innovation policy } \\
\text { facilitating innovation } \\
\text { industries in R\&D and } \\
\text { commercialization }\end{array}$ & $\begin{array}{l}\text { European Planning Studies; } \\
\text { Economic Development } \\
\text { Quarterly }\end{array}$ & $\begin{array}{c}3 \\
3,5 \%\end{array}$ \\
\hline Other & $\begin{array}{l}\text { E.g., Creation of new } \\
\text { business fields, clusters, and } \\
\text { systems }\end{array}$ & $\begin{array}{l}\text { American Journal of } \\
\text { Sociology; RAND Journal of } \\
\text { Economics }\end{array}$ & $\begin{array}{c}4 \\
5 \%\end{array}$ \\
\hline Total & & & $\begin{array}{c}81 \\
100 \%\end{array}$ \\
\hline
\end{tabular}


Table 4. Identified network approaches to commercialization and their conceptualizations on the phenomenon.

\begin{tabular}{|c|c|c|c|}
\hline $\begin{array}{l}\text { Identified } \\
\text { network } \\
\text { approach }\end{array}$ & $\begin{array}{c}\text { Narrower descriptions } \\
\text { of the approach }\end{array}$ & $\begin{array}{l}\text { Number } \\
\text { of } \\
\text { studies }\end{array}$ & $\begin{array}{l}\text { Approaches' emphasis and } \\
\text { conceptualizations of the } \\
\text { phenomenon }\end{array}$ \\
\hline $\begin{array}{l}\text { Interorganizational } \\
\text { network - IMP } \\
\text { approach }\end{array}$ & $\begin{array}{l}\text { - IMP school (relying } \\
\text { on, e.g., Ford \& } \\
\text { Håkansson, 2002); } \\
\text { research highlights } \\
\text { interaction and } \\
\text { operational } \\
\text { relationships for } \\
\text { commercialization. }\end{array}$ & 12 & \multirow{2}{*}{$\begin{array}{l}\text { Emphasis: relationships, partnerships, } \\
\text { alliances, and collaborations between } \\
\text { organizations formed for } \\
\text { commercialization } \\
\text { Conceptualizations employed: } \\
\text { interorganizational network, network } \\
\text { for collaboration, commercialization } \\
\text { network, collaborative network, } \\
\text { relationships in innovation for } \\
\text { technology commercialization, inter- } \\
\text { firm relationships, and innovation } \\
\text { partners } \\
\text { IMP-approach: e.g., Story et al., } 2011 \\
\text { Strategic network approach: e.g., de } \\
\text { Reuver \& Bouwman, 2012; Mu \& Di } \\
\text { Benedetto, } 2011\end{array}$} \\
\hline $\begin{array}{l}\text { Interorganizational } \\
\text { network - Strategic } \\
\text { networks }\end{array}$ & $\begin{array}{l}\text { - Strategic network } \\
\text { (relying on, e.g., } \\
\text { Gulati, 1998); } \\
\text { research highlights } \\
\text { how relations for } \\
\text { commercialization are } \\
\text { formed to manage } \\
\text { future competition. }\end{array}$ & 11 & \\
\hline Social networks & $\begin{array}{l}\text { - Social network ties } \\
\text { and structure (relying } \\
\text { on, e.g., Granovetter, } \\
\text { 1973; Burt, 1998; } \\
\text { Uzzi, 1996), user } \\
\text { networks, opinion } \\
\text { leaderships in social } \\
\text { networks, and } \\
\text { communities at macro } \\
\text { level impact adoption } \\
\text { and thus also } \\
\text { commercialization. }\end{array}$ & 19 & $\begin{array}{l}\text { Emphasis: networks between users or } \\
\text { opinion leader individuals or } \\
\text { communities formed and employed for } \\
\text { commercialization } \\
\text { Conceptualizations employed: adoption } \\
\text { network, diffusion network, user } \\
\text { network, networks of users, peer } \\
\text { networks, peer communities, opinion } \\
\text { leaders, social network, advice } \\
\text { networks, and communication networks } \\
\text { e.g., Iyengar et al., 2011; Bohlmann et } \\
\text { al., } 2010\end{array}$ \\
\hline \multirow[t]{2}{*}{$\begin{array}{l}\text { Network } \\
\text { economics }\end{array}$} & $\begin{array}{l}\text { - Network externalities } \\
\text { (relying on Katz \& } \\
\text { Shapiro 1985). }\end{array}$ & 7 & \multirow{2}{*}{$\begin{array}{l}\text { Emphasis: industry actors and public } \\
\text { actors interacting for commercialization } \\
\text { Conceptualizations employed: } \\
\text { networked business system, industry } \\
\text { networks, and networking within }\end{array}$} \\
\hline & $\begin{array}{l}\text { - Business and industry } \\
\text { clusters. }\end{array}$ & 6 & \\
\hline
\end{tabular}




\begin{tabular}{|c|c|c|c|}
\hline & & & $\begin{array}{l}\text { clusters } \\
\text { e.g., Chiesa \& Frattini, 2011; Molina- } \\
\text { Castillo et al., } 2011\end{array}$ \\
\hline $\begin{array}{l}\text { Innovation } \\
\text { networks }\end{array}$ & $\begin{array}{l}\text { - Innovation networks } \\
\text { include networking } \\
\text { also for } \\
\text { commercialization } \\
\text { activities. }\end{array}$ & 6 & $\begin{array}{l}\text { Emphasis: the innovator firm's } \\
\text { networks and collaboration throughout } \\
\text { the innovation process from R\&D to } \\
\text { commercialization } \\
\text { Conceptualizations employed: } \\
\text { innovation network, the network of the } \\
\text { innovator, strategic NPD networks, and } \\
\text { supporting organizations } \\
\text { e.g., Perks \& Moxey, } 2011\end{array}$ \\
\hline $\begin{array}{l}\text { Entrepreneur } \\
\text { networks }\end{array}$ & $\begin{array}{l}\text { - Networking and } \\
\text { partnering for growth } \\
\text { and } \\
\text { internationalization in } \\
\text { relation to } \\
\text { commercialization } \\
\text { (relying on, e.g., } \\
\text { Coviello \& Munro } \\
\text { 1995; Johanson \& } \\
\text { Vahlne 2009). } \\
\end{array}$ & 6 & $\begin{array}{l}\text { Emphasis: SMEs' and entrepreneurs' } \\
\text { networking for commercialization } \\
\text { Conceptualizations employed: new } \\
\text { venture networks; entrepreneurs' } \\
\text { networks } \\
\text { e.g., Freeman et al., 2010; Tolstoy \& } \\
\text { Agndal, } 2010\end{array}$ \\
\hline $\begin{array}{l}\text { Network } \\
\text { organization }\end{array}$ & $\begin{array}{l}\text { Project organizations } \\
\text { and collaboration of } \\
\text { small related firms } \\
\text { facilitate } \\
\text { commercialization } \\
\text { (relying on, e.g., } \\
\text { Kogut, 2000). }\end{array}$ & 4 & $\begin{array}{l}\text { Emphasis: internal and } \\
\text { interorganizational teams and projects } \\
\text { for commercialization } \\
\text { Conceptualizations employed: } \\
\text { collaborative teams, collaborative } \\
\text { project organization } \\
\text { e.g., Bercovitz \& Feldman, } 2011\end{array}$ \\
\hline $\begin{array}{l}\text { Actor Network } \\
\text { Theory (ANT) }\end{array}$ & $\begin{array}{l}\text { - Societal network of } \\
\text { human and non- } \\
\text { human actors support } \\
\text { the innovation } \\
\text { (relying on, e.g., } \\
\text { Latour 2005, Law } \\
\text { 1998). }\end{array}$ & 2 & $\begin{array}{l}\text { Emphasis: the innovation is actualized } \\
\text { with the support of the entire network } \\
\text { Conceptualizations employed: } \\
\text { supporters of innovation, "the macro- } \\
\text { cosmos" of innovation } \\
\text { e.g., Harty, } 2010\end{array}$ \\
\hline
\end{tabular}


Table 5. Synthesis of network actors and their expected contribution to commercialization in the reviewed studies.

\begin{tabular}{|c|c|c|}
\hline Relevant actors & Contribution to commercialization & $\begin{array}{c}\text { Examples of } \\
\text { references }\end{array}$ \\
\hline $\begin{array}{l}\text { Consumers, } \\
\text { clients, users, and } \\
\text { adopters } \\
\text { (individuals; } \\
\text { organizations) }\end{array}$ & $\begin{array}{l}\text { - Users support communication } \\
\text { o they serve as references, provide } \\
\text { endorsements, spread word-of-mouth, teach } \\
\text { others } \\
\circ \text { they represent the need for the innovation } \\
\circ \text { they present benefits, display use, diffuse } \\
\text { knowledge on new applications and utilization } \\
\text { experiences, and advance evaluation of } \\
\text { perceived risk regarding adoption } \\
\text { - Users judge product quality and give product } \\
\text { feedback, induce changes to products, generate new } \\
\text { applications, generate ideas on possible uses, and } \\
\text { develop functionality. } \\
\text { - Users give feedback regarding market structure, sales, } \\
\text { and promotion. } \\
\text { Adopters/users make the use and the user base visible } \\
\text { to other actors and build an impression of a "critical } \\
\text { mass" of adopters that impacts further diffusion. }\end{array}$ & $\begin{array}{l}\text { Vowles et al., } \\
2011 ; \\
\text { Van Siyke et al., } \\
\text { 2007; } \\
\text { Perks \& Moxey, } \\
2011 ; \\
\text { Tolstoy \& } \\
\text { Agndal, } 2010\end{array}$ \\
\hline $\begin{array}{l}\text { Key user entities: } \\
\text { lead users, opinion } \\
\text { leaders, and hubs } \\
\text { (individuals; } \\
\text { organizations) }\end{array}$ & $\begin{array}{l}\text { Lead users and opinion leaders serve as role models } \\
\text { as they act ahead of the mass market and influence } \\
\text { opinion formation/change. Consequently, they raise } \\
\text { the pace of the information stream and the adoption } \\
\text { process itself. } \\
\text { - Lead users assess products' market potential, and test } \\
\text { and evaluate the extent to which new products meet } \\
\text { significant user needs. } \\
\text { - Lead users facilitate the dissemination of knowledge } \\
\text { as they often straddle boundaries between different } \\
\text { clusters and groups; they teach how a new product } \\
\text { works and explain its benefits compared to what is } \\
\text { currently available. } \\
\text { Opinion leaders and lead users serve as important } \\
\text { references in further marketing. }\end{array}$ & $\begin{array}{l}\text { Hienerth \& Lettl, } \\
2011 ; \\
\text { Iyengar et al., } \\
2011 ; \\
\text { van Eck et al., } \\
2011 ; \\
\text { Goldenberg et al., } \\
2009 ; \\
\text { Harrison \& } \\
\text { Waluszewski, } \\
2008\end{array}$ \\
\hline $\begin{array}{l}\text { Communities; } \\
\text { macro } \\
\text { communities of } \\
\text { users (peers; } \\
\text { villages; } \\
\text { neighborhood; }\end{array}$ & $\begin{array}{l}\text { - A community stimulates public awareness within the } \\
\text { group, mobilizes community members, and organizes } \\
\text { information sharing activities: conferences, journals, } \\
\text { seminars, meetings, and discussions. } \\
\text { - A community creates pull effects. }\end{array}$ & $\begin{array}{l}\text { Hienerth \& Lettl, } \\
\text { 2011; } \\
\text { Song et al., } 2009\end{array}$ \\
\hline
\end{tabular}




\begin{tabular}{|c|c|c|}
\hline industry branch) & $\begin{array}{l}\text { - Community members test and use new } \\
\text { technologies/products and share knowledge on end } \\
\text { user requirements. } \\
\text { - Some community members are boundary spanners, } \\
\text { influence members of broader communities, and } \\
\text { outsiders, and signal through lead user status. }\end{array}$ & \\
\hline $\begin{array}{l}\text { Distributors, } \\
\text { retailers, and } \\
\text { intermediaries }\end{array}$ & $\begin{array}{l}\text { - Distributors provide distribution resources and make } \\
\text { the product available to users. }\end{array}$ & $\begin{array}{l}\text { Lettl et al., 2008; } \\
\text { Perks \& Moxey, } \\
2011\end{array}$ \\
\hline $\begin{array}{l}\text { Suppliers, } \\
\text { manufacturers, and } \\
\text { subcontractors }\end{array}$ & $\begin{array}{l}\text { - Suppliers and manufacturers increase the use of the } \\
\text { technology/innovation, e.g., through licensing. } \\
\text { - Suppliers implement applications and complementary } \\
\text { offerings. }\end{array}$ & $\begin{array}{l}\text { Story et al., 2008; } \\
\text { Story et al., 2011; } \\
\text { Tolstoy\& } \\
\text { Agndal, 2010; } \\
\text { Perks \& Moxey, } \\
2011\end{array}$ \\
\hline $\begin{array}{l}\text { Experts: designers, } \\
\text { engineers, and } \\
\text { consultants }\end{array}$ & $\begin{array}{l}\text { - Expert organizations increase organizational learning } \\
\text { on commercialization. }\end{array}$ & $\begin{array}{l}\text { Robertson et al., } \\
\text { 1996; } \\
\text { Story et al., } 2008\end{array}$ \\
\hline $\begin{array}{l}\text { Complementaries: } \\
\text { related companies } \\
\text { and partners that } \\
\text { supply products or } \\
\text { services } \\
\text { complementary to } \\
\text { an innovation }\end{array}$ & $\begin{array}{l}\text { - Complementaries together with other companies } \\
\text { develop the industry; they create future demand by } \\
\text { developing new business fields and constructing new } \\
\text { long-range orientations through strategic and } \\
\text { technology forecasting. } \\
\text { - Complementaries can innovate new sub-elements of } \\
\text { an offering, provide complementary solutions, resell } \\
\text { products and services, and fortify demand for new } \\
\text { products (e.g., they might require their clients to use } \\
\text { the innovation); thus, they stimulate the size of the } \\
\text { installed base and the variety of complementary } \\
\text { products. } \\
\text { - Collaboration with complementaries can save on } \\
\text { effort and reduce the high costs of marketing. } \\
\text { Collaboration enhances organizational learning and } \\
\text { market intelligence, and builds new knowledge on } \\
\text { commercialization. } \\
\text { Complementaries facilitate growth: } \\
\text { O they identify potential customers, suppliers, } \\
\text { and consultants } \\
\text { o they can provide access to global markets } \\
\text { Collaboration with complementaries increases the } \\
\text { credibility of the innovator firm and its product, and } \\
\text { provides reputational benefits. }\end{array}$ & $\begin{array}{l}\text { de Reuver \& } \\
\text { Bouwman, 2012; } \\
\text { Molina-Castillo } \\
\text { et al., 2011; } \\
\text { Perks \& Moxey, } \\
\text { 2011; } \\
\text { Snow et al., } 2011\end{array}$ \\
\hline Investors; vendors & $\begin{array}{l}\text { - Vendor investment directly impacts } \\
\text { commercialization. Investors also enable innovator } \\
\text { firms to find partners/companies seeking to fund. }\end{array}$ & $\begin{array}{l}\text { Inganäs et al., } \\
\text { 2007; Danov et } \\
\text { al., } 2003\end{array}$ \\
\hline
\end{tabular}




\begin{tabular}{|c|c|c|}
\hline $\begin{array}{l}\text { Public } \\
\text { organizations, non- } \\
\text { profit organization } \\
\text { associations, and } \\
\text { educational } \\
\text { institutions }\end{array}$ & $\begin{array}{l}\text { Public organizations engage in the development of an } \\
\text { innovation and its use, and articulate encouraging } \\
\text { visions for the use of the innovation in society. } \\
\text { - They establish trust, expertise, stability, credibility, } \\
\text { and a good reputation. } \\
\text { - They foster relations with political authorities. }\end{array}$ & $\begin{array}{l}\text { Troshani \& Hill, } \\
2009 ; \\
\text { Robertson et al., } \\
1996 ; \\
\text { Aarikka-Stenroos } \\
\text { \& Sandberg, } \\
2012\end{array}$ \\
\hline $\begin{array}{l}\text { Trade and } \\
\text { professional } \\
\text { associations }\end{array}$ & $\begin{array}{l}\text { - Associations as neutral knowledge brokers } \\
\text { disseminate information and generate trust. } \\
\text { - Associations with professional involvement tend to } \\
\text { diminish perceived bias; their actors are from multiple } \\
\text { sectors with multiple interests and thus provide } \\
\text { extensive unbiased visions on best practices. }\end{array}$ & $\begin{array}{l}\text { Aarikka-Stenroos } \\
\text { \& Sandberg, } \\
\text { 2012; } \\
\text { Troshani \& Hill, } \\
\text { 2009; Story et al., } \\
2008\end{array}$ \\
\hline $\begin{array}{l}\text { Universities, } \\
\text { academics, } \\
\text { research centers } \\
\text { and researchers }\end{array}$ & $\begin{array}{l}\text { - Academics and university researchers bring scientific } \\
\text { internationally informed knowledge. } \\
\text { - Science partners generate trust and credibility } \\
\text { regarding the innovation. } \\
\text { - Academics and experts teach and research different } \\
\text { facets of innovations. }\end{array}$ & $\begin{array}{l}\text { Bercovitz, \& } \\
\text { Feldman, 2011; } \\
\text { Johnson, 2008; } \\
\text { Inganäs et al., } \\
2007\end{array}$ \\
\hline $\begin{array}{l}\text { Policy makers, } \\
\text { regulators, public } \\
\text { sector actors, } \\
\text { government, } \\
\text { politicians, NGOs, } \\
\text { authorities, } \\
\text { municipalities, and } \\
\text { economic } \\
\text { development } \\
\text { agencies }\end{array}$ & $\begin{array}{l}\text { - Policy makers set, control and shape standards that } \\
\text { impact commercialization. } \\
\text { - Public sector actors provide information within their } \\
\text { own areas of expertise. } \\
\text { - Policy makers influence markets and investors. } \\
\text { - Institutions increase technological absorption, } \\
\text { promote local networking, link experts, legitimize } \\
\text { actors, involve actors in new collaborations, and make } \\
\text { the whole cluster more efficient. } \\
\text { - Policy makers fund individual projects and thus } \\
\text { provide financial resources. }\end{array}$ & $\begin{array}{l}\text { Story et al., 2008; } \\
\text { Tolfree, 2008; } \\
\text { Inganäs et al., } \\
2007\end{array}$ \\
\hline The media & $\begin{array}{l}\text { - The media build awareness and disseminate } \\
\text { information on an innovation and the company. }\end{array}$ & $\begin{array}{l}\text { Aarikka-Stenroos } \\
\text { \& Sandberg, } \\
2012\end{array}$ \\
\hline $\begin{array}{l}\text { Industries as a } \\
\text { whole: "all market } \\
\text { players"; } \\
\text { "members of } \\
\text { clusters" }\end{array}$ & $\begin{array}{l}\text { - Members of an industry identify commercial } \\
\text { opportunities and extend scientific knowledge and } \\
\text { access to financial resources. } \\
\text { - Industry actors together control and shape standards } \\
\text { and develop industries. } \\
\text { - Markets create push and pull mechanisms. } \\
\text { - Collaboration impacts the emergence of industry } \\
\text { architectures and processes leading to institutional } \\
\text { collective action. }\end{array}$ & $\begin{array}{l}\text { Chiesa \& } \\
\text { Frattini, 2011; } \\
\text { Sillanpää \& } \\
\text { Laamanen, 2009; } \\
\text { Powell et al., } \\
\text { 2005; } \\
\text { Van de Ven, } \\
\text { 2005; } \\
\text { Pittaway et al., } \\
2004\end{array}$ \\
\hline
\end{tabular}


Table 6. The research agenda: Identified research gaps and examples of research questions.

\begin{tabular}{|c|c|c|}
\hline Identified gap & Potential topics & Potential research questions \\
\hline $\begin{array}{l}\text { Perspectives of } \\
\text { multiple actors are } \\
\text { absent }\end{array}$ & $\begin{array}{l}\text { Different } \\
\text { perspectives of } \\
\text { involved actors to } \\
\text { innovation } \\
\text { commercialization. }\end{array}$ & $\begin{array}{l}\text { - How do divergent relevant actors perceive the } \\
\text { innovation and their role in commercialization? }\end{array}$ \\
\hline $\begin{array}{l}\text { Research on } \\
\text { management of } \\
\text { divergent } \\
\text { relationships for } \\
\text { commercialization is } \\
\text { sparse }\end{array}$ & $\begin{array}{l}\text { Management of } \\
\text { business } \\
\text { relationships in } \\
\text { networks of } \\
\text { commercialization; } \\
\text { orchestrating } \\
\text { commercialization } \\
\text { networks. }\end{array}$ & $\begin{array}{l}\text { - How can an innovator firm identify relevant } \\
\text { network actors for successful } \\
\text { commercialization? } \\
\text { - How are relevant network actors mobilized and } \\
\text { committed for successful commercialization? } \\
\text { - How can divergent actors be orchestrated in the } \\
\text { network for commercialization? } \\
\text { - How can the contribution potential of the } \\
\text { (loosely tied) supporters and facilitators of a } \\
\text { commercialization network be grasped? }\end{array}$ \\
\hline $\begin{array}{l}\text { Longitudinal data are } \\
\text { absent }\end{array}$ & $\begin{array}{l}\text { Evolution of the: } \\
\text { - commercialization } \\
\text { network } \\
\text { - commercialization } \\
\text { process }\end{array}$ & $\begin{array}{l}\text { - How does the commercialization network } \\
\text { evolve in terms of actors and their contribution } \\
\text { over time? } \\
\text { - How are innovations established in the } \\
\text { networked markets? } \\
\text { - What kind of learning occurs in the innovator } \\
\text { firm through interaction with commercialization } \\
\text { network actors? }\end{array}$ \\
\hline $\begin{array}{l}\text { Some relevant } \\
\text { network actors are } \\
\text { neglected }\end{array}$ & $\begin{array}{l}\text { Distributors' roles in } \\
\text { commercialization } \\
\text { networks; } \\
\text { Non-profit } \\
\text { organizations' roles } \\
\text { in commercialization } \\
\text { networks. }\end{array}$ & $\begin{array}{l}\text { - What kinds of role can distributors play as } \\
\text { actors in a commercialization network? } \\
\text { - What kinds of role can non-profit actors play as } \\
\text { actors in a commercialization network? }\end{array}$ \\
\hline $\begin{array}{l}\text { Diverse } \\
\text { commercialization } \\
\text { contexts and } \\
\text { innovation types are } \\
\text { not compared }\end{array}$ & $\begin{array}{l}\text { Contextual } \\
\text { understanding on } \\
\text { commercialization } \\
\text { networks. }\end{array}$ & $\begin{array}{l}\text { - What kinds of commercialization network can } \\
\text { be identified in diverse industries? } \\
\text { - What are the relevance and particular features of } \\
\text { commercialization networks in divergent } \\
\text { innovation contexts? } \\
\text { - How do commercialization networks for radical } \\
\text { and incremental innovation differ? }\end{array}$ \\
\hline $\begin{array}{l}\text { Commercialization } \\
\text { and } \\
\text { adoption/diffusion } \\
\text { research perspectives } \\
\text { are not combined }\end{array}$ & $\begin{array}{l}\text { The link between } \\
\text { commercialization } \\
\text { and adoption } \\
\text { networks. }\end{array}$ & $\begin{array}{l}\text { - How can adoption networks be orchestrated to } \\
\text { contribute to commercialization? }\end{array}$ \\
\hline
\end{tabular}




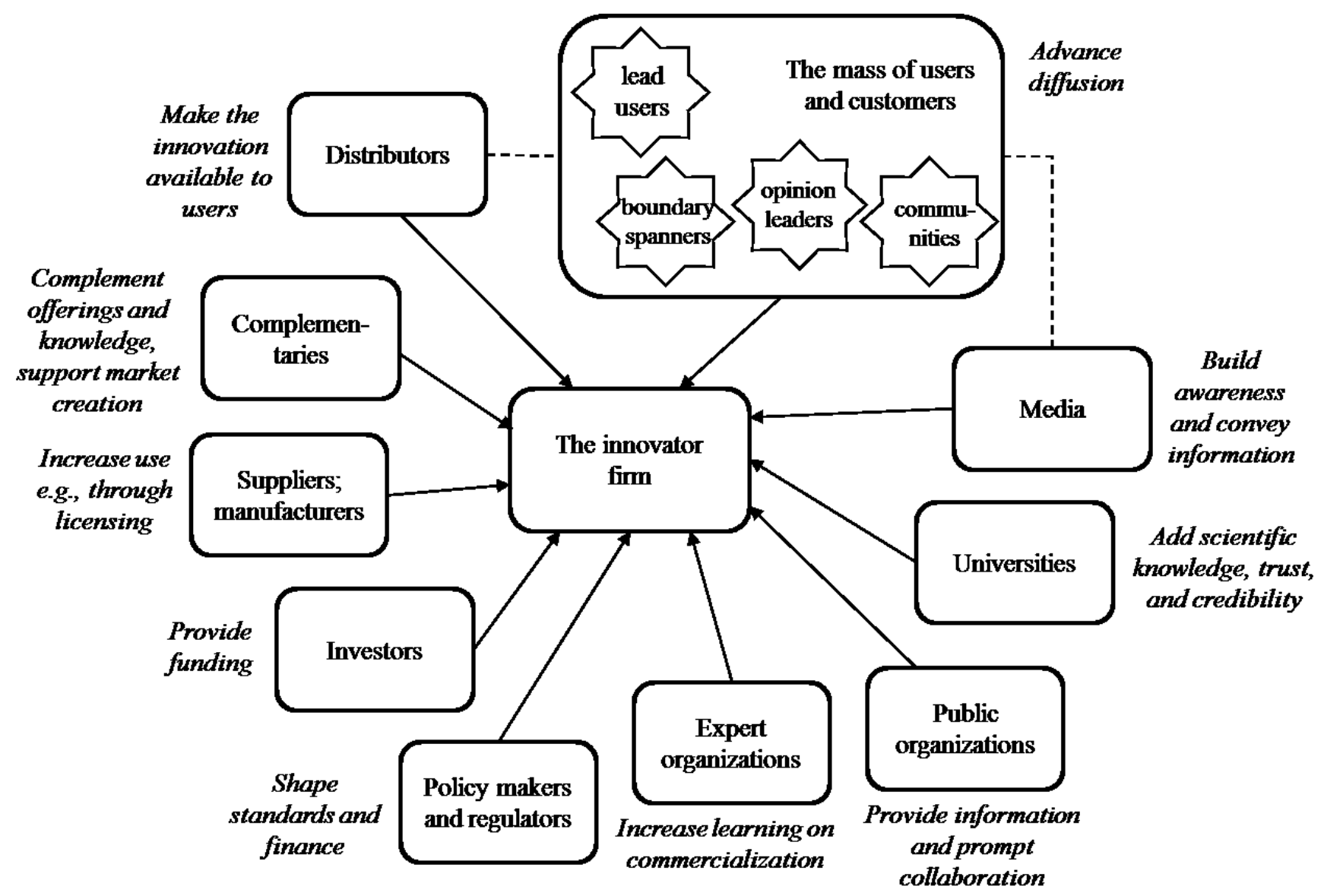

$\longrightarrow$ Contribution to commercialization

Contribution to commercialization due to supportive linkages with users and customers

Figure 1. An integrative framework: the network actors and their main contributions to commercialization 


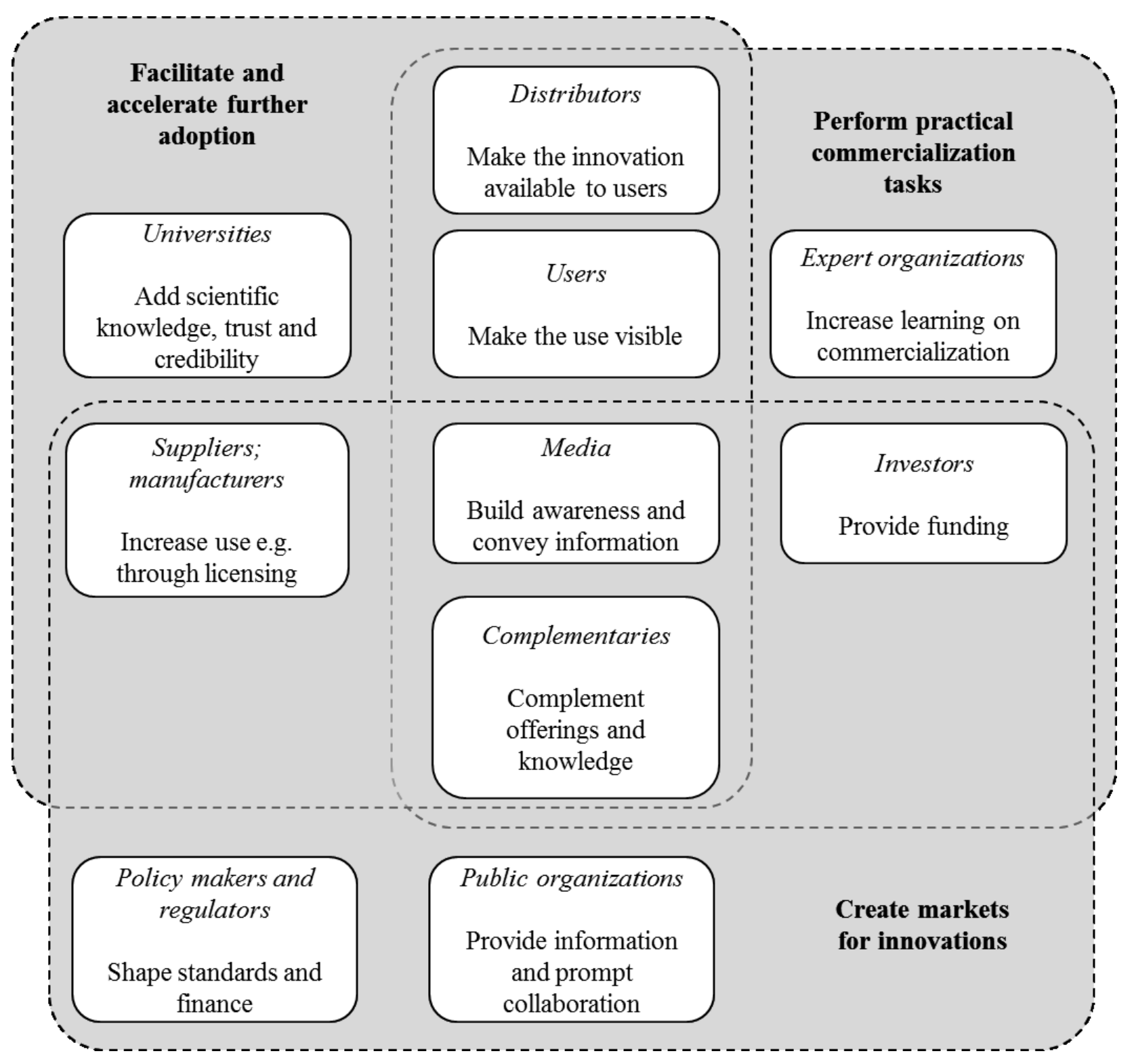

Figure 2 The three key contribution types and the actors with individual contribution potentials to commercialization - An illustrative example 


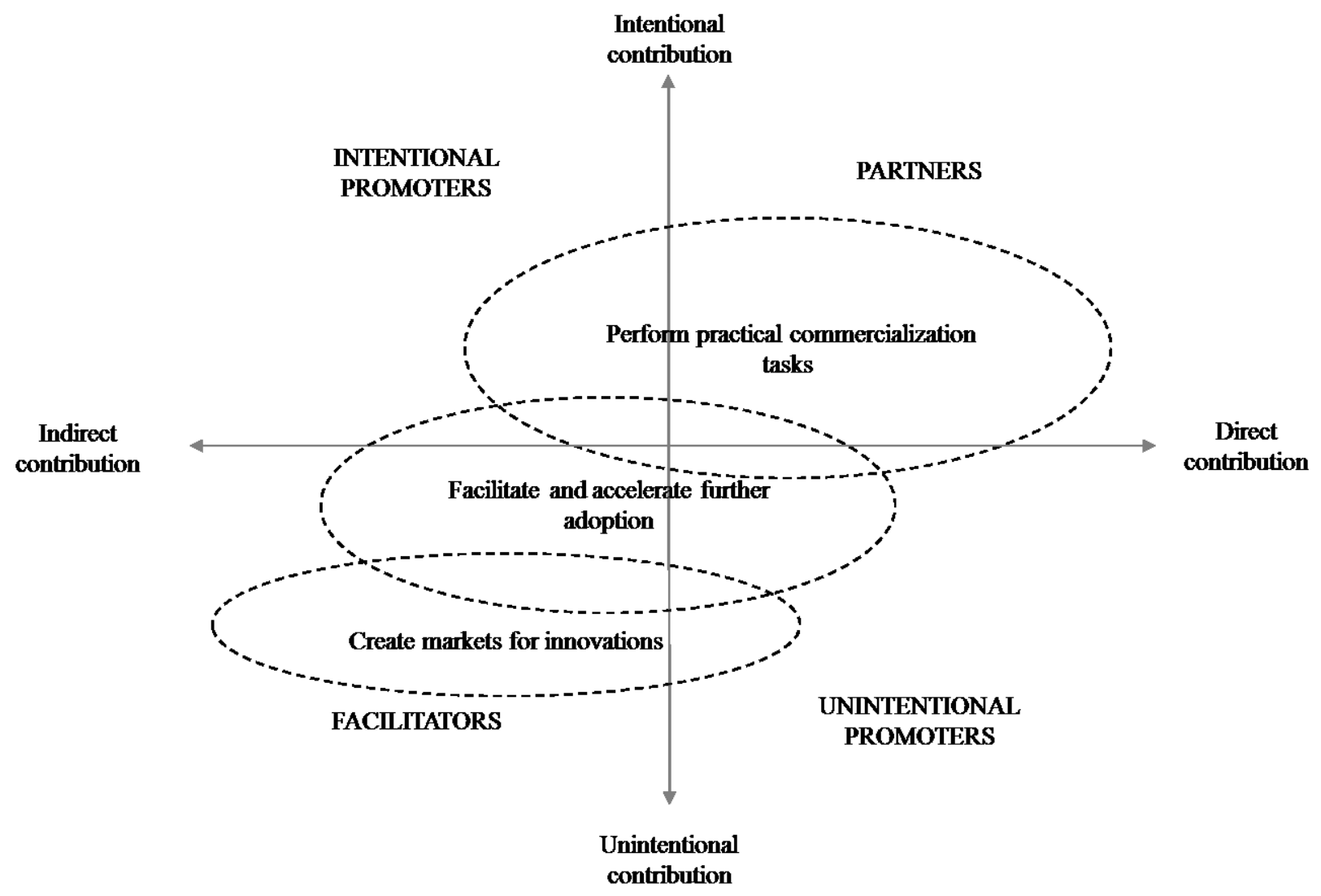

Figure 3 Modes of contribution 
Appendix 1. SEARCH LOG-Commercialization networks

\begin{tabular}{|c|c|c|c|c|c|c|c|c|c|c|}
\hline Search & Result & New limiter & Result & New limiter & Result & New limiter & Result & New limiter & Results & Remarks on search/limiters \\
\hline commerciali* + net* & 197 & commercialization & 53 & new products & 12 & $\begin{array}{l}\text { technological } \\
\text { innovation }\end{array}$ & 39 & $\begin{array}{l}\text { business } \\
\text { networks }\end{array}$ & 15 & $A B$ \\
\hline commerciali* + net* & 4 & new products & 30 & $\begin{array}{l}\text { innovation } \\
\text { adoption }\end{array}$ & 36 & $\begin{array}{l}\text { diffusion of } \\
\text { innovations }\end{array}$ & 94 & $\begin{array}{l}\text { business } \\
\text { networks }\end{array}$ & 29 & $\mathrm{TI}$ \\
\hline diffus* + net* & 1029 & new products & 30 & $\begin{array}{l}\text { innovation } \\
\text { adoption }\end{array}$ & 36 & $\begin{array}{l}\text { diffusion of } \\
\text { innovations }\end{array}$ & 94 & $\begin{array}{l}\text { business } \\
\text { networks }\end{array}$ & 29 & $A B$ \\
\hline diffus* + net* & 134 & $\begin{array}{l}\text { diffusion } \\
\text { networks }\end{array}$ & 19 & $\begin{array}{l}\text { technological } \\
\text { innovation }\end{array}$ & 15 & $\begin{array}{l}\text { social } \\
\text { networks }\end{array}$ & 26 & & & $\mathrm{TI}$ \\
\hline adopt* + net* & 4018 & $\begin{array}{l}\text { diffusion of } \\
\text { innovations }\end{array}$ & 48 & $\begin{array}{l}\text { social } \\
\text { networks }\end{array}$ & 140 & $\begin{array}{l}\text { product } \\
\text { management }\end{array}$ & 38 & $\begin{array}{l}\text { technological } \\
\text { innovations }\end{array}$ & 190 & $A B$ \\
\hline adopt* + net* & 88 & $\begin{array}{l}\text { business } \\
\text { networks }\end{array}$ & 7 & $\begin{array}{l}\text { social } \\
\text { networks }\end{array}$ & 13 & $\begin{array}{l}\text { technological } \\
\text { innovations }\end{array}$ & 10 & $\begin{array}{l}\text { innovation } \\
\text { adoption }\end{array}$ & 10 & $\mathrm{TI}$ \\
\hline launch* + net* & 831 & new products & 44 & $\begin{array}{l}\text { product } \\
\text { launches }\end{array}$ & 8 & $\begin{array}{l}\text { social } \\
\text { networks }\end{array}$ & 16 & $\begin{array}{l}\text { technological } \\
\text { innovation }\end{array}$ & 34 & $A B$ \\
\hline launch* + net* & 18 & new products & 3 & & & & & & & $\mathrm{TI}$ \\
\hline commerciali* + net* & 52 & commercialization & 15 & $\begin{array}{l}\text { business } \\
\text { networks }\end{array}$ & 9 & new products & 7 & $\begin{array}{l}\text { innovations } \\
\text { in business }\end{array}$ & 5 & Com $A B$ and net $\mathrm{TI}$ \\
\hline commerciali* + net* & 31 & commercialization & 15 & $\begin{array}{l}\text { business } \\
\text { networks }\end{array}$ & 6 & $\begin{array}{l}\text { technological } \\
\text { innovations }\end{array}$ & 6 & $\begin{array}{l}\text { innovations } \\
\text { in business }\end{array}$ & 3 & Com $\mathrm{TI}$ and net $\mathrm{AB}$ \\
\hline diffus* + net* & 356 & $\begin{array}{l}\text { diffusion of } \\
\text { innovations }\end{array}$ & 30 & $\begin{array}{l}\text { social } \\
\text { networks }\end{array}$ & 56 & $\begin{array}{l}\text { technological } \\
\text { innovations }\end{array}$ & 37 & & & Diffus $A B$ and net $\mathrm{TI}$ \\
\hline diffus* + net* & 320 & $\begin{array}{l}\text { diffusion of } \\
\text { innovations }\end{array}$ & 59 & new products & 15 & $\begin{array}{l}\text { social } \\
\text { networks }\end{array}$ & 34 & & & Diffus $\mathrm{TI}$ and net $\mathrm{AB}$ \\
\hline adopt* + net* & 1269 & new products & 18 & $\begin{array}{l}\text { business } \\
\text { networks }\end{array}$ & 54 & $\begin{array}{l}\text { social } \\
\text { networks }\end{array}$ & 79 & $\begin{array}{l}\text { product } \\
\text { management }\end{array}$ & 13 & Adopt $A B$ and net $\mathrm{TI}$ \\
\hline adopt* + net* & 279 & $\begin{array}{l}\text { innovation } \\
\text { adoption }\end{array}$ & 29 & $\begin{array}{l}\text { technological } \\
\text { innovations }\end{array}$ & 35 & $\begin{array}{l}\text { business } \\
\text { networks }\end{array}$ & 10 & $\begin{array}{l}\text { social } \\
\text { networks }\end{array}$ & 18 & Adopt $\mathrm{TI}$ and net $\mathrm{AB}$ \\
\hline launch* +net & 175 & social networks & 9 & $\begin{array}{l}\text { business } \\
\text { networks }\end{array}$ & 8 & $\begin{array}{l}\text { technological } \\
\text { innovations }\end{array}$ & 7 & & & Launch $\mathrm{AB}$ and net $\mathrm{TI}$ \\
\hline launch*+net* & 73 & new products & 9 & & & & & & & Launch $\mathrm{TI}$ and net $A B$ \\
\hline
\end{tabular}




\section{Appendix 2. Analyzed articles}

2012

Aarikka-Stenroos, Leena; Sandberg, Birgitta. From new-product development to commercialization through networks. Journal of Business Research, Vol. 65, Issue 2, pp. 198-206.

de Reuver, Mark; Bouwman, Harry. Governance mechanisms for mobile service innovation in value networks. Journal of Business Research, Vol. 65, Issue 3, pp.347-354

Shim, Seonyoung; Lee, Byungtae. Sustainable competitive advantage of a system goods innovator in a market with network effects and entry threats. Decision Support Systems, Vol. 52, Issue 2, pp. 308-317.

2011

Bercovitz, Janet; Feldman, Maryann. The mechanisms of collaboration in inventive teams: Composition, social networks, and geography. Research Policy, Vol. 40 , Issue 1, pp. 81-93.

Chiesa, Vittorio; Frattini, Federico. Commercializing Technological Innovation: Learning from Failures in High-Tech Markets. Journal of Product Innovation Management, Vol. 28 , Issue 4, pp. 437-454.

Dewald, Ulrich; Truffer, Bernhard. Market Formation in Technological Innovation Systems-Diffusion of Photovoltaic Applications in Germany. Industry \& Innovation, Vol. 18, Issue 3, pp. 285-300.

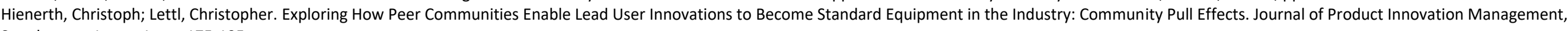

Supplement, Issue s1, pp. 175-195.

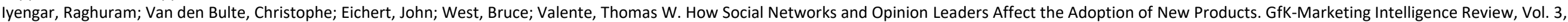

Issue 1, pp. 16-25.

Iyengar, Raghuram; Van den Bulte, Christophe; Valente, Thomas W. Opinion Leadership and Social Contagion in New Product Diffusion. Marketing Science, Vol. 30 , Issue 2, pp. 195-212.

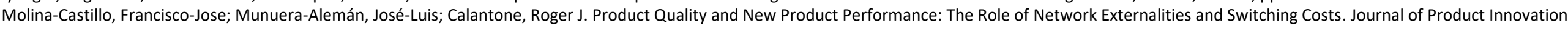

Management, Vol. 28, Issue 6, pp. 915-929.

Mu, Jifeng; Di Benedetto, C. Anthony. Strategic orientations and new product commercialization: mediator, moderator, and interplay. R\&D Management, Vol. 41, Issue 4, pp. 337-359.

Perks, Helen; Moxey, Steven. Market-facing innovation networks: How lead firms partition tasks, share resources and develop capabilities. Industrial Marketing Management, Vol. 40, Issue 8, pp. $1224-1237$.

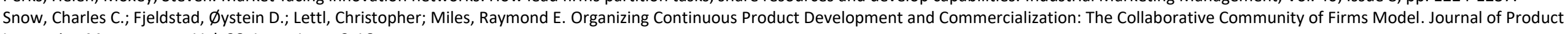

Innovation Management, Vol. 28, Issue 1, pp. 3-16.

Story, Vicky; O'Malley, Lisa; Hart, Susan. Roles, role performance, and radical innovation competences. Industrial Marketing Management, Vol. 40, Issue 6, pp. $952-966$.

van Eck, Peter S.; Jager, Wander; Leeflang, Peter S. H. Opinion Leaders' Role in Innovation Diffusion: A Simulation Study. Journal of Product Innovation Management, Vol. 28, Issue 2, pp. 187-203.

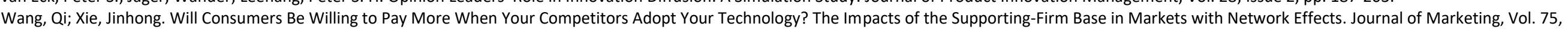
Issue 5, pp. 1-17.

Vowles, Nicole; Thirkell, Peter; Sinha, Ashish. Different determinants at different times: B2B adoption of a radical innovation. Journal of Business Research, Vol. 64 , Issue 11, pp. 1162-1168.

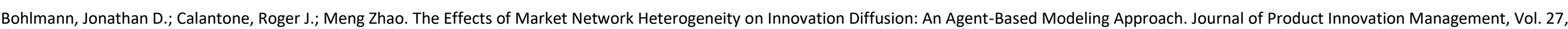
Issue 5, pp. 741-760.

Choi, Hanool; Kim, Sang-Hoon; Lee, Jeho. Role of network structure and network effects in diffusion of innovations. Industrial Marketing Management, Vol. 39 , Issue 1, pp. 170-177.

Decker, Reinhold; Gnibba-Yukawa, Kumiko. Sales Forecasting in High-Technology Markets: A Utility-Based Approach. Journal of Product Innovation Management, Vol. 27, Issue 1, pp. 115-129.

Freeman, Susan; Hutchings, Kate; Lazaris, Miria; Zyngier, Suzanne. A model of rapid knowledge development: The smaller born-global firm. International Business Review, Vol. 19, Issue 1, pp. 70-84.

Gobbo, José Alcides; Olsson, Annika. The transformation between exploration and exploitation applied to inventors of packaging innovations. Technovation, Vol. 30 , Issue 5/6, pp. 322-331.

Harty, Chris. Implementing innovation: designers, users and actor-networks. Technology Analysis \& Strategic Management, Vol. 22, Issue 3, pp. $297-315$.

Mas, Ignacio; Ng'weno, Amolo. Three keys to M-PESA's success: Branding, channel management and pricing. Journal of Payments Strategy \& Systems, Vol. 4, Issue 4, pp. 352-370.

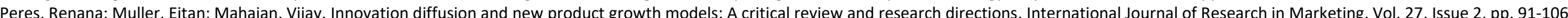
Tolstoy, Daniel; Agndal, Henrik. Network resource combinations in the international venturing of small biotech firms. Technovation, Vol. 30, Issue 1, pp. 24-36. 
Engel, Jerome S.; del-Palacio, Itxaso. Global networks of clusters of innovation: Accelerating the innovation process. Business Horizons, Vol. 52, Issue 5, pp. 493-503. Galeotti, Andrea; Goyal, Sanjeev. Influencing the influencers: a theory of strategic diffusion. RAND Journal of Economics, Vol. 40, Issue 3, pp. 509-532.

Goldenberg, Jacob; Han, Sangman; Lehmann, Donald R; Hong, Jae Weon. The Role of Hubs in the Adoption Process. Journal of Marketing, Vol. 73, Issue 2, pp. 1-13.

Kratzer, Jan; Lettl, Christopher. Distinctive Roles of Lead Users and Opinion Leaders in the Social Networks of Schoolchildren. Journal of Consumer Research, Vol. 36 , Issue 4, pp. 646-659.

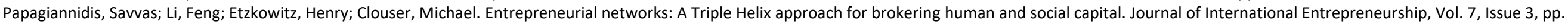

215-235.

Sillanpää, Antti; Laamanen, Tomi. Positive and negative feedback effects in competition for dominance of network business systems. Research Policy, Vol. 38, Issue 5, pp. 871-884.

Song, Michael; Parry, Mark E.; Kawakami, Tomoko. Incorporating Network Externalities into the Technology Acceptance Model. Journal of Product Innovation Management, Vol. 26, Issue 3, pp. 291-307.

Stam, Wouter. When does community participation enhance the performance of open source software companies? Research Policy, Vol. 38, Issue 8, pp. 1288-1299.

Story, Vicky; Hart, Susan; O'Malley, Lisa. Relational resources and competences for radical product innovation. Journal of Marketing Management, Vol. 25, Issue 5/6, pp. 461-481.

Troshani, Indrit; Hill, Sally Rao. Linking stakeholder salience with mobile services diffusion. International Journal of Mobile Communications, Vol. 7, Issue 3, pp. $269-289$.

Alcouffe, Simon; Berland, Nicolas; Levant, Yves. Actor-networks and the diffusion of management accounting innovations: A comparative study. Management Accounting Research, Vol. 19, Issue 1, pp. 1-17.

Glick, J. Leslie. Biotechnology business models work: Evidence from the pharmaceutical marketplace. Journal of Commercial Biotechnology, Vol. 14, Issue 2, pp. 106-117.

Harrison, Debbie; Waluszewski, Alexandra. The development of a user network as a way to re-launch an unwanted product. Research Policy, Vol. 37, Issue 1, pp. 115-130.

Harryson, Sigvald J. Entrepreneurship through relationships - navigating from creativity to commercialisation. R\&D Management, Vol. 38, Issue 3, pp. 290-310.

Harryson, Sigvald J.; Dudkowski, Rafal; Stern, Alexander. Transformation Networks in Innovation Alliances - The Development of Volvo C70. Journal of Management Studies, Vol. 45, Issue 4, pp. 745-773.

Johnson, William H.A. Roles, resources and benefits of intermediate organizations supporting triple helix collaborative R\&D: The case of Precarn. Technovation, Vol. 28, Issue 8, pp. 495-505.

Katzy, Bernhard R.; Crowston, Kevin. Competency rallying for technical innovation-The case of the Virtuelle Fabrik. Technovation, Vol. 28, Issue 10, pp. 679-692.

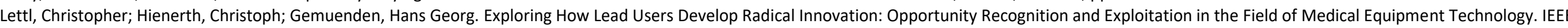

Transactions on Engineering Management, Vol. 55, Issue 2, pp. 219-233.

Millson, Murray R.; Wilemon, David. Designing strategic innovation networks to facilitate global NPD performance. Journal of General Management, Vol. 34 , Issue 2, pp. $39-56$.

Story, Vicky; O'Malley, Lisa; Hart, Susan; Saker, Jim. The development of relationships and networks for successful radical innovation. Journal of Customer Behaviour, Vol. 7, Issue 3, pp. 187-200.

Styles, Chris; Genua, Tina. The rapid internationalization of high technology firms created through the commercialization of academic research. Journal of World Business, Vol. 43, Issue 2, pp. 146-157.

Tolfree, David. Progress in commercialising micro-nanotechnology in the UK. International Journal of Technology Transfer \& Commercialisation, Vol. 7, Issue 4, pp. $284-289$.

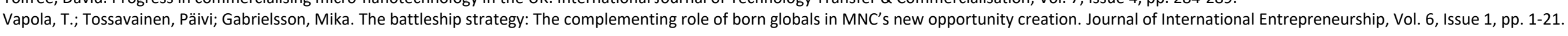

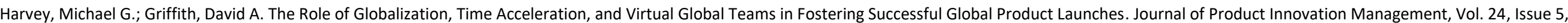
pp. 486-501.

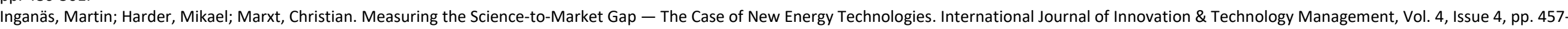
478.

Low, Brian; Johnston, Wesley J.; Wang, Jennifer. Securing network legitimacy in China's telecommunication market. Journal of Business \& Industrial Marketing, Vol. 22, Issue 2, pp. 97-106.

Stuart, Toby E.; Ozdemir, Salih Zeki; Ding, Waverly W. Vertical alliance networks: The case of university-biotechnology-pharmaceutical alliance chains. Research Policy, Vol. 36, Issue 4, pp. 477-498.

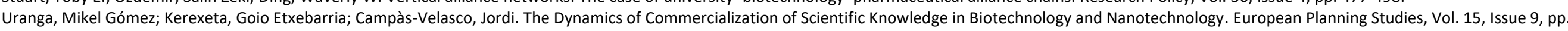
1199-1214.

Van Siyke, Craig; Ilie, Virginia; Hao Lou; Stafford, Thomas. Perceived critical mass and the adoption of a communication technology. Journal of Information Systems, Vol. 16 , Issue 3, pp. 270-283. 


\begin{tabular}{|c|c|}
\hline & Organisations, Vol. 3, Issue 3, pp. 3-3 \\
\hline 2005 & 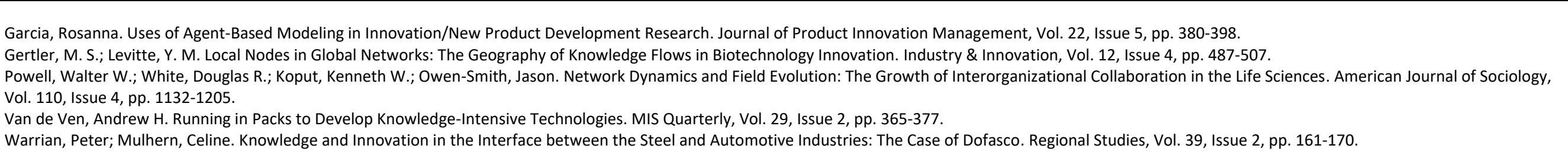 \\
\hline 2004 & 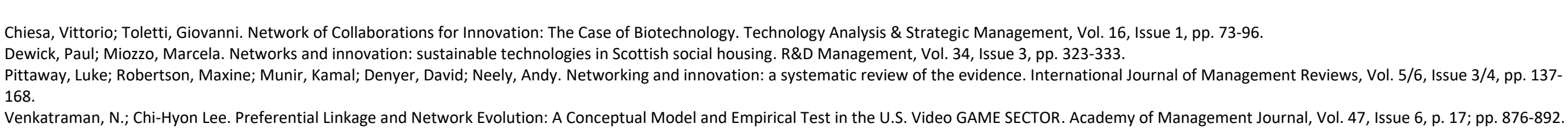 \\
\hline 2003 & $\begin{array}{l}\text { Danov, Michael A.; Smith, J. Brock; Mitchell, Ronald K. Relationship Prioritization for Technology Commercialization. Journal of Marketing Theory \& Practice, Vol. 11, Issue 3, pp. 59-70. } \\
\text { Torres, Ann M.; Murray, John A. The Role of Networks in Venture Creation Among Irish Software Firms. Irish Marketing Review, Vol. 16, Issue 1, pp. 5-14. } \\
\text { Yikuan Lee; O'Connor, Gina Colarelli. New Product Launch Strategy for Network Effects Products. Journal of the Academy of Marketing Science, Vol. 31, Issue 3, pp. 241-255. }\end{array}$ \\
\hline 2001 & 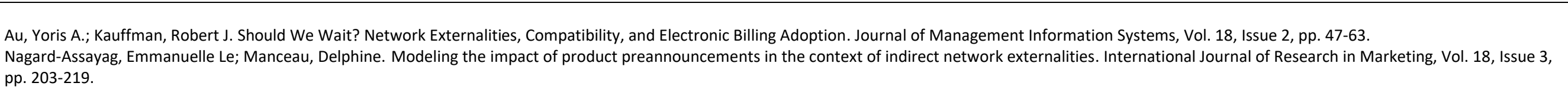 \\
\hline 2000 & $\begin{array}{l}\text { Hage, Jerald; Hollingsworth, J. Rogers. A Strategy for the Analysis of Idea Innovation Networks and Institutions. Organization Studies, Vol. 21, Issue 5, pp. } 971 . \\
\text { Steward, Fred; Conway, Steve. Building Networks for Innovation Diffusion in Europe: Learning from the SPRINT Programme. Enterprise \& Innovation Management Studies, Vol. 1, Issue 3, pp. 281-301. }\end{array}$ \\
\hline 1998 & $\begin{array}{l}\text { Johannisson, Bengt. Personal networks in emerging knowledge-based firms: spatial and functional patterns. Entrepreneurship \& Regional Development, Vol. 10, Issue 4, pp. } 297-312 . \\
\text { Wood, Samuel C.; Brown, Gary S. Commercializing Nascent Technology: The Case of Laser Diodes at Sony. Journal of Product Innovation Management, Vol. 15, Issue 2, pp. 167-183. }\end{array}$ \\
\hline 1996 & Robertson, Maxine; Swan, Jacky; Newell, Sue. The Role of Networks in the Diffusion of Technological Innovation. Journal of Management Studies, Vol. 33, Issue 3, pp. 333-359. \\
\hline 1995 & Tidd, Joe. Development of Novel Products Through Intraorganizational and Interorganizational Networks. Journal of Product Innovation Management, Vol. 12, Issue 4, pp. 307-322. \\
\hline 1993 & 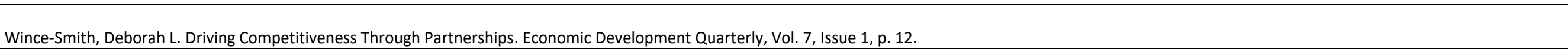 \\
\hline 1992 & \\
\hline
\end{tabular}

